\title{
26. Fe-Ti OXIDE MINERALOGY OF DSDP LEG 55 BASALTS
}

\author{
Masaru Kono, Geophysical Institute, University of Tokyo, Bunkyo-ku, Tokyo 113, Japan \\ David Clague, Middlebury College, Middlebury, Vermont \\ and \\ Edwin E. Larson, Department of Geological Sciences, University of Colorado, Boulder, Colorado
}

\section{INTRODUCTION}

Magnetic properties of volcanic rocks are controlled mainly by the physical and chemical state of their constituent ferromagnetic minerals. The most important parameters determining magnetic properties are concentration, composition, grain size, and oxidation state. In sea floor basalts, the main ferromagnetic minerals are titanomagnetites which are either unoxidized or, more commonly, have undergone various degrees of posteruptive low-temperature oxidation to become cationdeficient titanomagnetites, or titanomaghemites. The effects of this low-temperature alteration are seen in the increase of Curie temperature and decrease of saturation magnetization and lattice parameter of ferromagnetic minerals (Readman and O'Reilly, 1972). It is now believed that titanomaghemitization of newly formed mid-ocean ridge crust proceeds with a time constant of about $1 \mathrm{~m} . \mathrm{y}$. , accompanying drastic decrease of the intensity of the natural remanent magnetization (NRM) (Johnson and Atwater, 1977).

Titanomaghemites also occur in subaerial volcanic rocks (e.g., Akimoto and Kushiro, 1960) but such occurrence is not universal as in sea floor basalts, and is usually related to some form of hydrothermal alteration (Ade-Hall et al., 1971). Most subaerial basalts show varying degrees of high-temperature oxidation of titanomagnetites, which took place at temperatures higher than $600^{\circ} \mathrm{C}$ while the basalts cooled from the initial molten state (Buddington and Lindsley, 1964; Ozima and Larson, 1970).

Until now, the distinction between the ferromagnetic minerals in sea floor basalts and those in seamount basalts has not been adequately recognized. Lowrie (1977) pointed out a systematic difference in the intensity of NRM of DSDP and dredged samples, where dredged samples were obtained primarily near active oceanic ridges or seamounts and DSDP samples correspond to more or less ordinary sea floor. In detailed rock magnetic studies of dredged submarine rocks, Ozima et al. (1974) concluded that "regardless of the origin of submarine basalts whether they are from seamount or sea floor, the ferromagnetic mineral in young submarine basalts are homogeneous Ti-rich titanomagnetite, whereas titanomaghemite is the major ferromagnetic mineral in older submarine basalts." Marshall (1978) also found that the ferromagnetic minerals in Hole 192A basalt from Meiji Seamount are highly cation-deficient titanomagnetites quite similar to those found in other
DSDP basalts drilled from the sea floor. Such a lack of distinction may be a result of insufficient sampling of seamount basalts; even on Meiji Seamount, only 13 meters of basaltic layer was penetrated.

Leg 55 of the Deep Sea Drilling Project (DSDP) offered a unique opportunity for studying seamount basalts. With penetrations into basaltic basement of 58.7 meters at Ojin (Hole 430A), 31.9 meters at Nintoku (Hole 432A), and 10.5, 23 and 387.5 meters at Suiko (Holes 433A, 433B, 433C), it is now possible to study the magnetic properties of seamount basalts in detail. It is the purpose of this paper to investigate the physical and chemical states of ferromagnetic minerals in these basalts and to compare them with those in sea floor basalts. Using the results of rock magnetic studies (Kono, this volume), we hope to characterize the ferromagnetic minerals in Emperor Seamount basalts and to make a comparison of magnetic mineralogy of sea floor and seamount basalts.

\section{OPTICAL MICROSCOPY}

Polished sections of about a hundred samples were studied under oil immersion using a Reitz microscope with reflection light attachment. A magnification of 1000 was used throughout the study. The purpose of this observation was to define optically the oxidation state of the samples. The oxidation type of samples was already defined by Kono (this volume) from the shape of thermomagnetic curves, but the oxidation stage was independently defined from the microscopic observations.

The high-temperature oxidation stages used in the present study are developed from the scheme of Larson et al. (1969). Basically, low, moderate, and high oxidation stages were distinguished by the presence or absence and abundance of ilmenite lamellae in titanomagnetite host and pseudobrookite. Other phenomena, such as granulation (Ade-Hall et al., 1971), metailmenites (oxidation product of ilmenite lamellae or ilmenite crystals, probably mixtures of pseudobrookite or rutile and hematite), and reddening and replacement of silicates by secondary iron oxides, were used as supporting evidence. Typical implications for each oxidation stage are as follows:

$\mathrm{N}$ : No oxidation. Only homogeneous grains present. Indication of oxidation (ilmenite lamellae, etc.) absent.

L: Low oxidation. Ilmenite lamellae not common. Silicates not affected. 
M: Moderate oxidation. Abundant ilmenite lamellae present. Some silicates may show reddening and/or replacement. Pseudobrookite not common.

H: High oxidation. Most of the original titanomagnetites and ilmenites replaced by pseudobrookite, hematite, and meta-ilmenite. Reddening and replacement of silicates common.

When some samples showed intermediate stages or when different grains in a sample showed different stages, the samples were designated as L-M, etc. Since such determination cannot be purely objective, we did not try to express the oxidation stages by the numbering system of Wilson and Haggarty (1966) and Ade-Hall et al. (1968); but our stages N, L, M, H may correspond to their Classes 1, 1-2, 3, 4-6, respectively.

The oxidation stages defined in the foregoing do not take the secondary alteration into account. Some of the samples also contain titanomaghemites and show irreversible thermomagnetic curves (oxidation type LT, see Kono, this volume). In most of these samples, titanomaghemitization of minerals was ascertained by microscopic observation of shrinkage cracks and color change from brownish gray to bluish gray near grain boundaries and cracks (e.g., Johnson and Hall, 1978).

Results of microscopic observations are summarized in Tables 1, 2, and 3. In these tables, a close correlation can be seen between the oxidation type LT (irreversible thermomagnetic curve indicating titanomaghemite) and the optically observed titanomaghemites. Hence, it can be concluded that thermomagnetic analysis under moderately high vacuum ( $\leqslant 10^{-4}$ Torr) is a good means for detecting titanomaghemites. If the ferromagnetic mineral is really one phase, measurements of the Curie point and the lattice parameter uniquely determine the composition of titanomaghemite (Readman and O'Reilly, 1972; T. Nishitani, in preparation).

Ferromagnetic minerals in Ōjin (Table 1) and Nintoku (Table 2) basalts show quite different oxidation conditions. Almost all the Ōjin samples show moderate to high oxidation, high Curie temperature, reversible thermomagnetic curve, and absence of secondary oxidation. On the other hand, many of the Nintoku samples have low to moderate Curie temperatures, irreversible thermomagnetic curves, and titanomaghemites. The original (high-temperature) oxidation was low to moderate in such samples. As they are alkalic basalts or hawaiites of similar ages drilled from similar depths of 1400 to 1600 meters, the basalts of the two seamounts may have experienced similar conditions at the time of eruption and afterwards. The difference in high-temperature oxidation states may have been caused by some local conditions, e.g., presence or absence of joints and cracks, availability of ground water, etc., at the time of initial emplacement. But at this stage, we cannot point out a plausible mechanism which caused such difference in oxidation environment.

In Suiko basalts, the degree of high-temperature oxidation is generally high, and most of the samples are free from the effects of low-temperature oxidation. Some of the minerals in lower oxidation stages show evidence of titanomaghemitization (Table 3). However, the occurrence of titanomaghemites seems unrelated to either the rock type (tholeiite or alkalic basalt) or the depth from the sea floor. Some of the lava flows contain both HT- and LT-type samples. The only distinction between these two types seems to be in the high-temperature oxidation stage. Figure 1 shows the histograms of Curie temperature and oxidation stages and a correction diagram between these two properties for all the Leg 55 samples. Apparently, the samples with titanomaghemites have undergone only low-temperature or low- to moderately high temperature oxidation. It is plausible that once the ferromagnetic minerals are highly oxidized at high temperatures, oxidation cannot proceed later at low temperatures even in a very oxidizing environment. High Curie temperature $\left(\gtrsim 500^{\circ} \mathrm{C}\right)$ by itself does not mean a high degree of oxidation; when

TABLE 1

Reflection Microscopy of Fe-Ti Oxides, Hole 430A

\begin{tabular}{|c|c|c|c|c|c|c|c|c|}
\hline $\begin{array}{c}\text { Sample } \\
\text { (Interval in } \mathrm{cm} \text { ) }\end{array}$ & $\begin{array}{l}\text { Flow } \\
\text { Unit }\end{array}$ & $\mathrm{T}_{\mathrm{c}}$ & Type & $\begin{array}{l}\text { Oxidation } \\
\text { Stage }\end{array}$ & $\begin{array}{l}\text { Ilmenite } \\
\text { Lamellae }\end{array}$ & $\begin{array}{l}\text { Pseudo- } \\
\text { brookite }\end{array}$ & $\begin{array}{l}\text { Titano- } \\
\text { maghemite }\end{array}$ & Remarks \\
\hline $5-2,30-32$ & $1(\mathrm{~A})$ & 520 & HT & $\mathrm{M}-\mathrm{H}$ & +++ & & & \\
\hline $5-3,107-109$ & 1 (A) & 503 & HT & $\mathrm{L}$ & & & & Homogeneous grains. \\
\hline $5-5,44-46$ & $2(\mathrm{~A})$ & 575 & HT & $\mathrm{H}$ & ++ & ++ & & $\begin{array}{l}\text { Ilmenite lamellae broken down to } \\
\text { hematite and pseudobrookite. } \\
\text { Olivines altered and contain patches } \\
\text { of red hematite. }\end{array}$ \\
\hline $5-5,103-105$ & $2(\mathrm{~A})$ & 583 & HT & $\mathrm{M}-\mathrm{H}$ & +++ & & & \\
\hline $6-1,67-69$ & 2 (A) & 575 & HT & $\mathrm{M}-\mathrm{H}$ & +++ & + & & Some silicate replaced by iron oxides. \\
\hline $6-1,88-90$ & $2(\mathrm{~A})$ & 576 & HT & $\mathrm{M}-\mathrm{H}$ & +++ & & & Some silicates replaced by iron oxides. \\
\hline $6-2,54-56$ & $3(\mathrm{~A})$ & 582 & HT & $\mathrm{M}-\mathrm{H}$ & ++ & & & $\begin{array}{l}\text { Titanomagnetite granulation. Patches } \\
\text { of hematite. }\end{array}$ \\
\hline $6-2,122-124$ & $3(\mathrm{~A})$ & 576 & HT & M & +++ & & & \\
\hline $6-4,15-17$ & $4(\mathrm{~A})$ & 577 & HT & $\mathrm{M}-\mathrm{H}$ & +++ & & & Replacement of silicates common. \\
\hline
\end{tabular}

Notes: Flow Unit column indicates flow unit number and type of rock: A, alkalic basalts, $\mathrm{T}$, tholeiites. $\mathrm{T}_{\mathrm{C}}=$ Curie temperature in ${ }^{\circ} \mathrm{C}$. Type $=$ type of thermomagnetic curve: NO, no oxidation, HT, high-temperature oxidation, LT, low-temperature oxidation. Oxidation Stage = degree of high-temperature oxidation of titanomagnetite: N, L, M, H = no, low, moderate, high oxidation. Ilmenite la mellae: presence of ilmenite lamellae in (111) planes of (titano-) magnetite host crystal. Pseudobrookite: presence of pseudobrookite as oxidation product of Ti-rich phase. Titanomaghemite: presence of low-temperature oxidation product. +++ abundant, ++ common, + present. 
TABLE 2

Reflection Microscopy of Fe-Ti Oxides, Hole 432A

\begin{tabular}{|c|c|c|c|c|c|c|c|c|}
\hline $\begin{array}{c}\text { Sample } \\
\text { (Interval in } \mathrm{cm} \text { ) }\end{array}$ & $\begin{array}{l}\text { Flow } \\
\text { Unit }\end{array}$ & $\mathrm{T}_{\mathrm{C}}$ & Type & $\begin{array}{l}\text { Oxidation } \\
\text { Stage }\end{array}$ & $\begin{array}{l}\text { Ilmenite } \\
\text { Lamellae }\end{array}$ & $\begin{array}{l}\text { Pseudo- } \\
\text { brookite }\end{array}$ & $\begin{array}{l}\text { Titano- } \\
\text { maghemite }\end{array}$ & Remarks \\
\hline $2-1,74-76$ & $1(\mathrm{~A})$ & 373 & LT & L-M & + & & + & $\begin{array}{l}\text { Early stage of maghemitization indicated by bluish- } \\
\text { gray tint and shrinkage cracks. }\end{array}$ \\
\hline $2-1,107-109$ & 1 (A) & 364 & LT & L-M & + & & + & Low-grade maghemitization. \\
\hline $2-2,23-25$ & 2 (A) & 575 & $\mathrm{HT}$ & $\mathrm{H}$ & ++ & +++ & & $\begin{array}{l}\text { Silicate replacement abundant. Ilmenite lamellae } \\
\text { replaced by pseudobrookite and hematite. }\end{array}$ \\
\hline $2-2,72-74$ & $2(\mathrm{~A})$ & 572 & HT & M & +++ & + & & Reddening of silicate common. \\
\hline $2-3,12-14$ & $2(\mathrm{~A})$ & 457 & LT & L-M & ++ & & + & $\begin{array}{l}\text { Titanomagnetite shows blue-gray color. Shrinkage } \\
\text { cracks present. }\end{array}$ \\
\hline $2-3,21-23$ & 2 (A) & & & L-M & ++ & & ++ & Moderate maghemitization. \\
\hline $3-2,67-69$ & $3(\mathrm{~A})$ & 187 & NO & $\mathrm{N}$ & & & & $\begin{array}{l}\text { Homogeneous equant titanomagnetite crystals of } \\
20 \mu \mathrm{m} \text { or less. Brown color. }\end{array}$ \\
\hline $4-1,64-66$ & $3(\mathrm{~A})$ & 550 & HT & M-H & +++ & + & & Abundant replacement of silicates. \\
\hline $4-1,120-122$ & $3(\mathrm{~A})$ & 391 & LT & $\mathrm{L}-\mathrm{M}$ & ++ & & ++ & $\begin{array}{l}\text { Wide ilmenite lamellae. Some big grains } 20-100 \mu \mathrm{m} \text {. } \\
\text { Maghemitization shown by bluish-gray color and } \\
\text { shrinkage cracks. }\end{array}$ \\
\hline $4-2,80-82$ & $3(\mathrm{~A})$ & 577 & HT & M & +++ & & trace & \\
\hline $5-2,69-71$ & $3(\mathrm{~A})$ & 299 & LT & L-M & + & & + & Pyrite is present, filling cracks in silicates and oxides. \\
\hline
\end{tabular}

Note: See Table 1 for explanation.

the high-temperature oxidation is incomplete and there exist multiple ferromagnetic phases with a distribution of Curie temperatures, it is usually not possible to observe any but the highest Curie temperatures.

\section{SCANNING ELECTRON MICROSCOPY}

Some of the samples used in optical observations were repolished, etched 3 minutes in $6 \mathrm{~N}$ hydrochloric acid, coated with evaporated gold, and observed using a scanning electron microscope (SEM). Since the number of samples observed by SEM is small, we do not claim that the following observations are characteristic of titanomagnetites in seamount basalts. However, the SEM observations illustrate several interesting features of the ferromagnetic minerals that could not be observed by any other means. The SEM used was a Cambridge Scientific Instruments model S4, equipped with a Kevex 5500 X-ray Energy Spectrometer, in the Department of Molecular Biology, University of Colorado, Boulder. Observations were carried out with an accelerating voltage of $20 \mathrm{kV}$ and magnifications between 500 and 15,000 . Some of the photographs are reproduced in Figures 2 through 4.

Figure 2a shows a titanomagnetite grain in Sample 432A-2-1, 74-76 cm at low magnification. The grain is homogeneous except for some irregular patches (dark gray) near some of the cracks and at the top right. The dark portion apparently corresponds to titanomaghemite. Since the low-temperature oxidation is not severe, the grain still keeps sharp boundaries, and shrinkage cracks are not common. Figure $2 \mathrm{~b}$ shows a different grain from the same sample. Again the mild low-temperature oxidation resulted in dark, irregular patches near cracks. More irregular cracks appear in the figure, but it may be simply because the magnification was larger (5000 times) or it may represent the effect of volume change caused by oxidation. A notable feature of Figure $2 b$ is the presence of minute ilmenite lamellae running parallel in two directions. These lamellae could not be observed by optical microscope, because of their small size. The SEM observations of this sample are consistent with the results of thermomagnetic and microscopic analyses (Table 2); high-temperature oxidation is mostly of low degree and there is indication of incipient titanomaghemitization.

Figure 3 shows a grain in Sample 432A-2-2, 72-74 cm at two magnifications. This sample is typical of the moderate (M) stage of high-temperature oxidation. The ilmenite lamellae are quite well developed. The thicker ones appear at spacings of about $2 \mu \mathrm{m}$; thinner ones are much more abundant, and their intervals are $0.5 \mu \mathrm{m}$ or less. Undoubtedly, the subdivision by fine lamellae reduces the effective grain size and causes high magnetic stability similar to single domain grains (Strangway et al., 1968). The coercive force $\left(H_{c}\right)$ and saturation remanence/magnetization ratio $\left(J_{r} / J_{S}\right)$ of this sample are 288 Oe and 0.206 (Kono, this volume), in good agreement with the above conclusion.

Figure 4 shows Sample 430A-5-5, 44-46 cm, which is a highly oxidized sample, according to microscopic observation (Table 1). Figure $4 a$ shows that in this grain, thick lamellae of 2 to $5 \mu \mathrm{m}$ are well developed mostly in two directions. The matrix (lighter) part appeared homogeneous, but when we went up to a magnification of 6100 (Figures 4b, 4c), we observed a large number of tiny lamellae in the matrix part. As in Sample 432A-2-2, 72-74 cm (Figure 3), the tiny lamellae divide the titanomagnetite matrix into cells of $0.5 \mu \mathrm{m}$ or less. Some of the thick lamellae contain dark patches (Figure $4 \mathrm{~b})$; perhaps they correspond to pseudobrookite, the oxidation product of ilmenite. This stage of oxidation is consistent with the microscopic observation, where some pseudobrookite is actually observed (Table 1).

The tiny lamellae in Figures $4 \mathrm{~b}$ and $4 \mathrm{c}$ are aligned in two directions, neither of which is parallel to the directions of larger lamellae. As the ilmenite lamellae exsolve in (111) planes of spinel structure, there are usually three directions in which lamellae appear when a titano- 
TABLE 3

Reflection Microscopy of Fe-Ti Oxides, Site 433

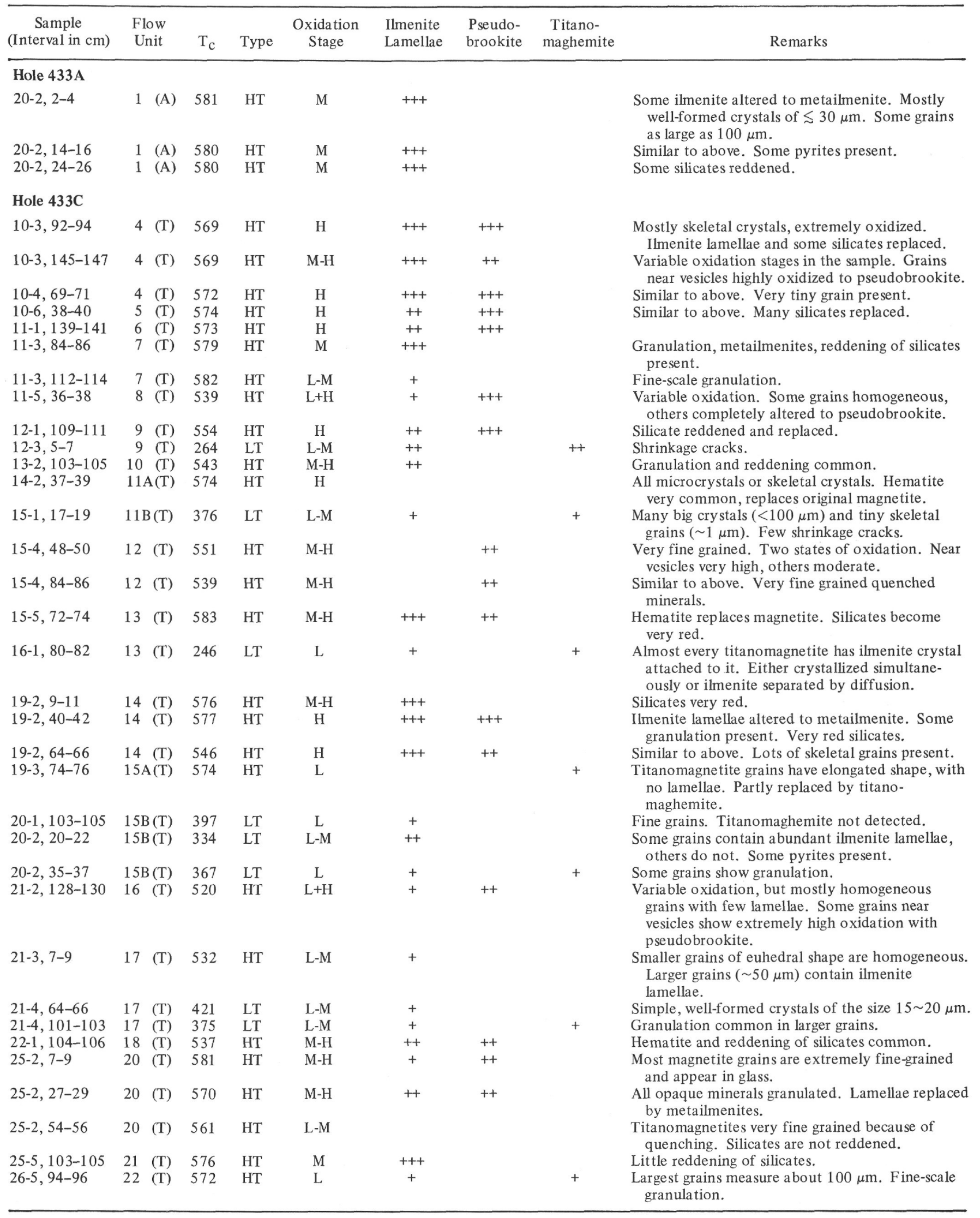


TABLE 3 - Continued

\begin{tabular}{|c|c|c|c|c|c|c|c|c|}
\hline $\begin{array}{c}\text { Sample } \\
\text { (Interval in } \mathrm{cm})\end{array}$ & $\begin{array}{l}\text { Flow } \\
\text { Unit }\end{array}$ & $\mathrm{T}_{\mathrm{c}}$ & Type & $\begin{array}{l}\text { Oxidation } \\
\text { Stage }\end{array}$ & $\begin{array}{l}\text { Ilmenite } \\
\text { Lamellae }\end{array}$ & $\begin{array}{l}\text { Pseudo- } \\
\text { brookite }\end{array}$ & $\begin{array}{l}\text { Titano- } \\
\text { maghemite }\end{array}$ & Remarks \\
\hline \multicolumn{9}{|l|}{ Hole 433C } \\
\hline $26-6,49-51$ & $23(\mathrm{~T})$ & 553 & HT & M & + & & & Tiny grains exist in glass. \\
\hline $26-6,129-131$ & $23(\mathrm{~T})$ & 535 & HT & M & + & & & $\begin{array}{l}\text { Ilmenites are large, bar-line crystals, but titano- } \\
\text { magnetites are very small. }\end{array}$ \\
\hline $27-5,41-43$ & $24(\mathrm{~T})$ & 541 & HT & M & & & & Quenched tiny crystals of titanomagnetite. \\
\hline $28-4,121-123$ & $26 \mathrm{~A}(\mathrm{~T})$ & 580 & HT & $\mathrm{M}-\mathrm{H}$ & & & & $\begin{array}{l}\text { Titanomagnetites are fine grained. Very red sili- } \\
\text { cates. Granulation common. }\end{array}$ \\
\hline $29-2,115-117$ & $26 \mathrm{~B}(\mathrm{~T})$ & 492 & LT & $\mathrm{M}-\mathrm{H}$ & & & & $\begin{array}{l}\text { Very fine grained titanomagnetites in the glass. } \\
\text { Very red silicates. }\end{array}$ \\
\hline $31-4,83-85$ & $28 \mathrm{~A}(\mathrm{~T})$ & 562 & HT & $\mathrm{M}-\mathrm{H}$ & & & & Same as above. \\
\hline $32-1,38-40$ & $28 \mathrm{~B}(\mathrm{~T})$ & 558 & HT & $\mathrm{M}-\mathrm{H}$ & & ++ & & Same as above. \\
\hline $32-1,112-114$ & $28 \mathrm{~B}(\mathrm{~T})$ & 582 & HT & $\mathrm{M}-\mathrm{H}$ & & & & Same as above. Pyrites common. \\
\hline $35-1,112-114$ & $35(\mathrm{~T})$ & 546 & HT & M-H & ++ & ++ & & Some granulation present. Grains are bigger. \\
\hline $35-6,48-50$ & $35(\mathrm{~T})$ & 557 & HT & $\mathrm{L}+\mathrm{H}$ & ++ & +++ & & $\begin{array}{l}\text { Variable oxidation states coexist: some grains are } \\
\text { homogeneous with no lamellae, others contain } \\
\text { pseudobrookite. }\end{array}$ \\
\hline $35-6,121-123$ & $36(\mathrm{~T})$ & 573 & HT & $\mathrm{H}$ & ++ & +++ & & $\begin{array}{l}\text { All the titanomagnetites oxidized to hematite and } \\
\text { pseudobrookite. Most silicates reddened and } \\
\text { replaced. }\end{array}$ \\
\hline $35-7,116-118$ & $36(\mathrm{~T})$ & 583 & HT & M-H & ++ & ++ & & $\begin{array}{l}\text { Mostly small grains in glass, but also some larger } \\
\text { grains of } \sim 20 \mu \mathrm{m} \text {. }\end{array}$ \\
\hline $36-1,45-47$ & $36(\mathrm{~T})$ & 576 & HT & M & ++ & & & Skeletal grains. Silicates are reddened. \\
\hline $36-1,105-107$ & $37(\mathrm{~T})$ & 577 & HT & M & ++ & & & Similar to above. \\
\hline $36-3,60-62$ & $38(\mathrm{~T})$ & 577 & HT & $\mathrm{M}-\mathrm{H}$ & ++ & ++ & & $\begin{array}{l}\text { Some large skeletal grains exist, but mostly small } \\
\text { grains }(2 \sim 3 \mu \mathrm{m}) \text {. Silicates are reddened. }\end{array}$ \\
\hline $36-4,56-58$ & 39 (T) & 528 & HT & L-M & & & & Fresh titanomagnetites of various size. \\
\hline $37-3,74-76$ & $44(\mathrm{~T})$ & 534 & HT & M & + & & & Very fine titanomagnetite grains abundant. \\
\hline $38-1,57-59$ & 45 (T) & 577 & HT & L-M & & & & No lamellae but small-scale granulation present. \\
\hline $38-5,119-121$ & 47 (T) & 364 & LT & $\mathrm{L}$ & & & + & Small-scale granulation. Some grains have cracks. \\
\hline $39-5,96-98$ & $48(\mathrm{~T})$ & 581 & HT & $\mathrm{L}-\mathrm{M}$ & & & & Some granulation. Silicates slightly reddened. \\
\hline $39-6,78-80$ & 48 (T) & 573 & HT & L-M & & & & Same as above. \\
\hline $41-1,51-53$ & $51 \mathrm{~B}(\mathrm{~T})$ & 573 & $\mathrm{HT}$ & M-H & +++ & ++ & & Silicates reddened. \\
\hline $42-1,68-70$ & $52(\mathrm{~T})$ & & & $\mathrm{M}-\mathrm{H}$ & +++ & ++ & & Same as above. \\
\hline $42-2,136-138$ & $53(\mathrm{~T})$ & 573 & HT & M-H & +++ & ++ & & Same as a bove. \\
\hline $42-5,134-136$ & $54(\mathrm{~T})$ & 425 & LT & M & ++ & + & + & $\begin{array}{l}\text { Small and large (up to } 200 \mu \mathrm{m} \text { ) grains coexist. A } \\
\text { few maghemite cracks. }\end{array}$ \\
\hline $43-1,33-35$ & $54(\mathrm{~T})$ & 578 & HT & $\mathrm{H}$ & +++ & +++ & & Silicates reddened. \\
\hline $44-1,41-43$ & $56(\mathrm{~T})$ & 578 & HT & $\mathrm{M}-\mathrm{H}$ & & & & $\begin{array}{l}\text { Abundant small crystals highly oxidized and } \\
\text { appear reddened. }\end{array}$ \\
\hline $44-4,108-110$ & $58(\mathrm{~T})$ & 553 & HT & M & & & & $\begin{array}{l}\text { Abundant fine titanomagnetite grains. Some } \\
\text { granulation and reddening of silicates. }\end{array}$ \\
\hline $45-2,45-47$ & $59(\mathrm{~T})$ & 553 & HT & $\mathrm{M}$ & & & & Similar to above. \\
\hline $45-5,51-53$ & $60(\mathrm{~T})$ & 371 & LT & L-M & + & & +++ & Larger grains are not much HT oxidized. \\
\hline $45-6,43-45$ & $60(\mathrm{~T})$ & 431 & LT & L-M & ++ & & ++ & Larger grains with ilmenite lamellae. \\
\hline $46-3,54-56$ & $60(\mathrm{~T})$ & 579 & HT & $\mathrm{H}$ & ++ & +++ & & $\begin{array}{l}\text { Pseudobrookite, metailmenite, reddening and } \\
\text { replacement of silicate very abundant. }\end{array}$ \\
\hline $47-1,26-28$ & $63(\mathrm{~T})$ & 579 & HT & M & ++ & & & $\begin{array}{l}\text { Large and small grains of titanomagnetite. Some } \\
\text { granulation. }\end{array}$ \\
\hline $47-5,25-27$ & 64 (A) & 472 & LT & M & & & & $\begin{array}{l}\text { Well-formed, equant crystals with some } \\
\text { granulation. }\end{array}$ \\
\hline $48-3,30-32$ & 64 (A) & 575 & HT & $\mathrm{M}-\mathrm{H}$ & ++ & ++ & & Reddened silicates abundant. \\
\hline $49-1,142-144$ & 66 (T) & 577 & HT & $\mathrm{M}-\mathrm{H}$ & +++ & ++ & & Same as a bove. \\
\hline $49-2,50-52$ & $66(\mathrm{~T})$ & 575 & HT & $\mathrm{M}-\mathrm{H}$ & ++ & ++ & & Similar to above. \\
\hline
\end{tabular}

Note: See Table 1 for explanation.

magnetite grain is cut at an arbitrary surface. The directions defined by tiny lamellae in Figure $4 \mathrm{~b}$ are all different from the directions of larger lamellae. Such difference is possible if the materials of the large and small lamellae are different. In fact, in some rocks, ulvospinel lamellae appear in (100) planes of magnetite because of solvus reaction. In the present sample, ulvospinel cannot be the material, since the oxidation state is high, but some other cubic material may really make up the tiny lamellae. A series of X-ray energy-dispersive spectra were taken by Kevex spectrometer. The portions where spectra shown in Figure 5 were obtained are marked in Figures $4 \mathrm{a}$ and $4 \mathrm{~b}$. Figure $5 \mathrm{a}$ shows the spectrum inside a thick ilmenite lamella in Figure 4b. Apart from peaks of gold at about 2 and $10 \mathrm{keV}$ (representing the sample surface coating), only the peaks of $\mathrm{Ti}$ and $\mathrm{Fe}$ rise above the noise level. Because the spectrometer is not calibrated for quantitative analysis, it is not possible to deter- 


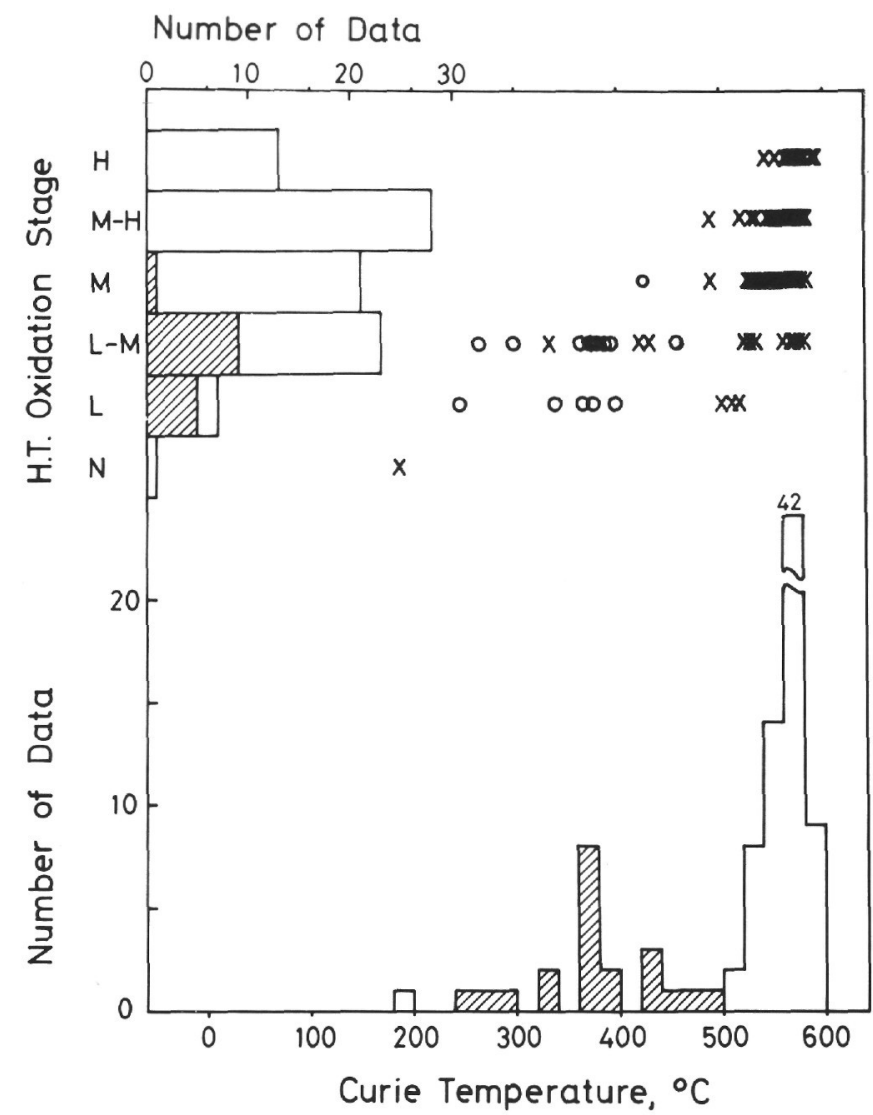

Figure 1. Histograms of Curie points (bottom) and high-temperature oxidation stages (upper left) and the correlation between these two properties (upper right). Samples containing low-temperature-oxidized phase are indicated by hachures and circles.

mine the exact ratio of $\mathrm{Fe}$ atoms to $\mathrm{Ti}$ atoms. It is reasonable to assume, however, that the ratio is close to 1 , corresponding to the composition of ilmenite. Figure $5 b$ shows the spectrum from another portion of Figure 4b. Since it is not possible to determine the composition of tiny lamellae, a mixture of lamellae and groundmass was measured. Figure $5 \mathrm{~b}$ shows that $\mathrm{Ti}$ is almost absent from this part, and that a considerable amount of $\mathrm{Al}$ is present in addition to $\mathrm{Fe}$. $\mathrm{Mg}$ may also be present, but we cannot be sure, because of the high background noise level near $1 \mathrm{keV}$. Figure $5 \mathrm{c}$ is a spectrum taken from a much larger area of the same grain (Figure 4a), and can be taken to represent the overall composition of this grain. Here, the Fe and Ti peaks are dominant, but the presence of $\mathrm{Al}$ and $\mathrm{Mg}$ is also certain. From Figure $5 \mathrm{~b}$ alone, we might have concluded that the tiny lamella is composed of either hercynite $\left(\mathrm{FeAl}_{2} \mathrm{O}_{4}\right)$ or spinel $\left(\mathrm{MgAl}_{2} \mathrm{O}_{4}\right)$, both of which have spinel structure. Since $\mathrm{Mg}$ apparently exists in this grain, however, it is more plausible that the tiny lamellae are of spinel composition. Lamella structure of spinel in titanomagnetite has not been reported, to our knowledge, but is plausible, since Katsura et al. (1976) report that spinel forms a perfect solid solution with titanomagnetite at high temperatures in the $\mathrm{TiFe}_{2} \mathrm{O}_{4}-\mathrm{Fe}_{3} \mathrm{O}_{4}-\mathrm{MgAl}_{2} \mathrm{O}_{4}$ ternary system, provided that the $\mathrm{MgAl}_{2} \mathrm{O}_{4}$ concentration is less than about 20 per cent. $\mathrm{Mg}$ and $\mathrm{Al}$ are also the most abundant "impurity" atoms in naturally occurring titanomagnetites (e.g., Creer and Ibbetson, 1970). Another important implication is that the matrix becomes very Ti-poor and tends toward almost pure magnetite $\left(\mathrm{Fe}_{3} \mathrm{O}_{4}\right)$ as the oxidation proceeds and lamellar structure develops, as shown in Figure $5 \mathrm{~b}$.

In the SEM studies, it was not possible to distinguish hematite from unoxidized magnetite. We do not know if this is a general limitation of SEM. But supplementary optical-microscopic observations can alleviate this deficiency quite well. The magnification of 15,000 is not a limit of SEM capability, but at higher magnifications, the images are so blurred that a good view cannot be obtained. This is perhaps a result of the magnetic field caused by minerals, which deflects the electron beams out of focus. A range of $1000 \times$ to $10,000 \times$ may be the optimum range for SEM observation of titanomagnetites.

\section{X-RAY MICROPROBE ANALYSES}

Results of microprobe analyses are summarized in Tables 4 through 6 . These tables list weight percentages of $\mathrm{TiO}_{2}, \mathrm{Al}_{2} \mathrm{O}_{3}, \mathrm{Cr}_{2} \mathrm{O}_{3}, \mathrm{FeO}, \mathrm{MgO}, \mathrm{MnO}$, and the totals, as well as composition parameters $x$ or $y$ for titanomagnetite, $x \mathrm{Fe}_{2} \mathrm{TiO}_{4} \cdot(1-x) \mathrm{Fe}_{3} \mathrm{O}_{4}$, or hemoilmenite, $y \mathrm{FeTiO}_{3} \cdot(1-y) \mathrm{Fe}_{2} \mathrm{O}_{3}$. The composition parameters were calculated using the following scheme. The $x$ values were calculated directly from $\mathrm{Ti} / \mathrm{Fe}$ ratios. $\mathrm{Al}, \mathrm{Cr}$, $\mathrm{Mg}$, and $\mathrm{Mn}$ were assumed as impurities. Some grains contain a considerable amount of $\mathrm{Cr}$; but in all cases there is enough $\mathrm{Mg}$ to form magnesiochromite $\left(\mathrm{MgCr}_{2} \mathrm{O}_{4}\right)$, so that our assumption is perhaps valid. In the derivation of $y, \mathrm{TiO}_{2}$ was assumed to be distributed among the ternary system geikielite $\left(\mathrm{MgTiO}_{3}\right)$-pyrophanite $\left(\mathrm{MnTiO}_{3}\right)$ -hemoilmenite. This assumption was necessary because in many crystals $\mathrm{Ti} / \mathrm{Fe}$ ratio exceeds one, indicating $y$ values larger than 1 . As geikielite and pyrophanite have the same crystal structure $(R \overline{3})$ as ilmenite, and as they are known to form solid solution with ilmenite, this assumption seems well founded. $\mathrm{Al}$ and $\mathrm{Cr}$ are again neglected in the calculation as impurities. Geikielite and pyrophanite component is about 10 mole per cent or less for most grains, but a few contain more than 20 mole per cent of these minerals.

Many of the data show low totals of 90 to about 95 per cent. Part of this mass deficiency is caused by taking total iron as $\mathrm{FeO}$. If we calculate the proper amount of $\mathrm{Fe}_{2} \mathrm{O}_{3}$ for each grain, part of the discrepancy can be accounted for. Since the electron beam of the microanalyzer is a few micrometers across, we are looking at some average composition of a grain. As the results of optical and electron microscopic observations show, most of our samples are oxidized to some extent. This means that the "titanomagnetite" phase may be either a mixture of ilmenite and magnetite or even a mixture of pseudobrookite and hematite. A similar situation exists with regard to the "hemoilmenite" phase. In such cases, we have more $\mathrm{Fe}_{2} \mathrm{O}_{3}$ at the expense of $\mathrm{FeO}$. But all the mass deficiency cannot be attributed to $\mathrm{Fe}^{2+} \rightarrow \mathrm{Fe}^{3+}$ changes, for two reasons: first, the deficiency remains in 


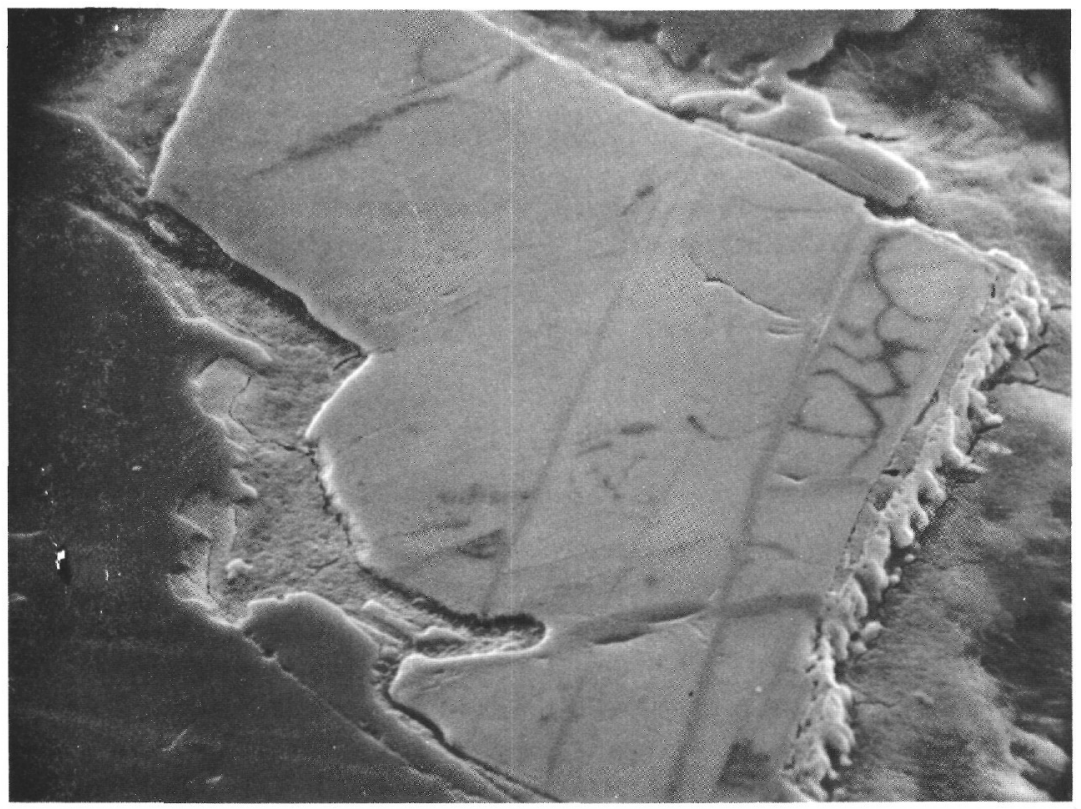

$2 a$

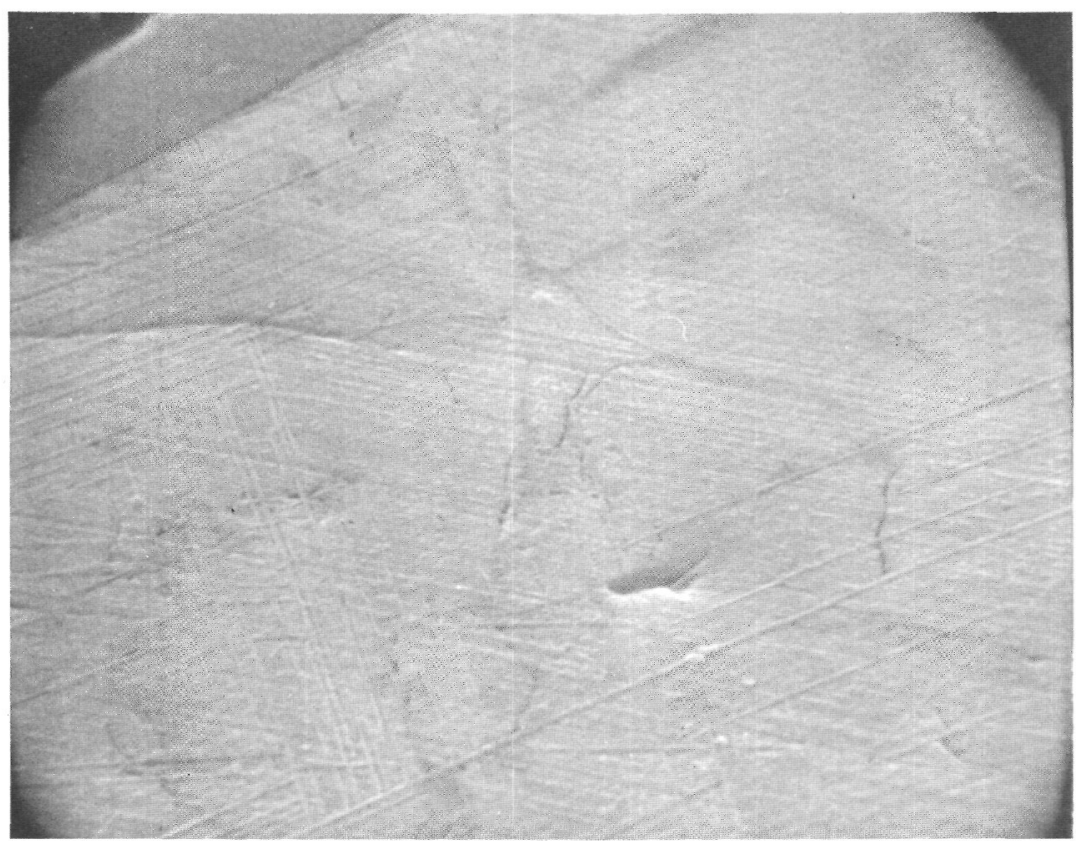

$2 b$

Figure 2. SEM photographs of Sample 432A-2-1, 74-76 cm, in which high-temperature oxidation is of low to moderate degree. (a) Nearly homogeneous titanomagnetite grain at $1000 \times$. Titanomaghemite appears as dark, irregular patches, but low-temperature oxidation is not severe. (b) Another grain at $5000 \times$, showing development of very fine ilmenite lamellae and irregular darker places which are perhaps titanomagnemites developed near cracks.

some samples even after we take all the iron as $\mathrm{Fe}^{3+}$; second, such a method of calculation would give a wide range of oxidation parameter $z$ for grains closely located in the same sample - for instance, in Sample 432A-5-2, $57-66 \mathrm{~cm}, z$ ranges from 0.15 to 0.73 , which is quite un- realistic. Therefore, the deficiency may show the effects of oxidation, as well as other impurity atoms (such as vanadium) not measured in our experiments.

Figure 6 shows the histograms of $x$ and $y$ for the present samples. The value of $x$ or $y$ of each grain is counted 


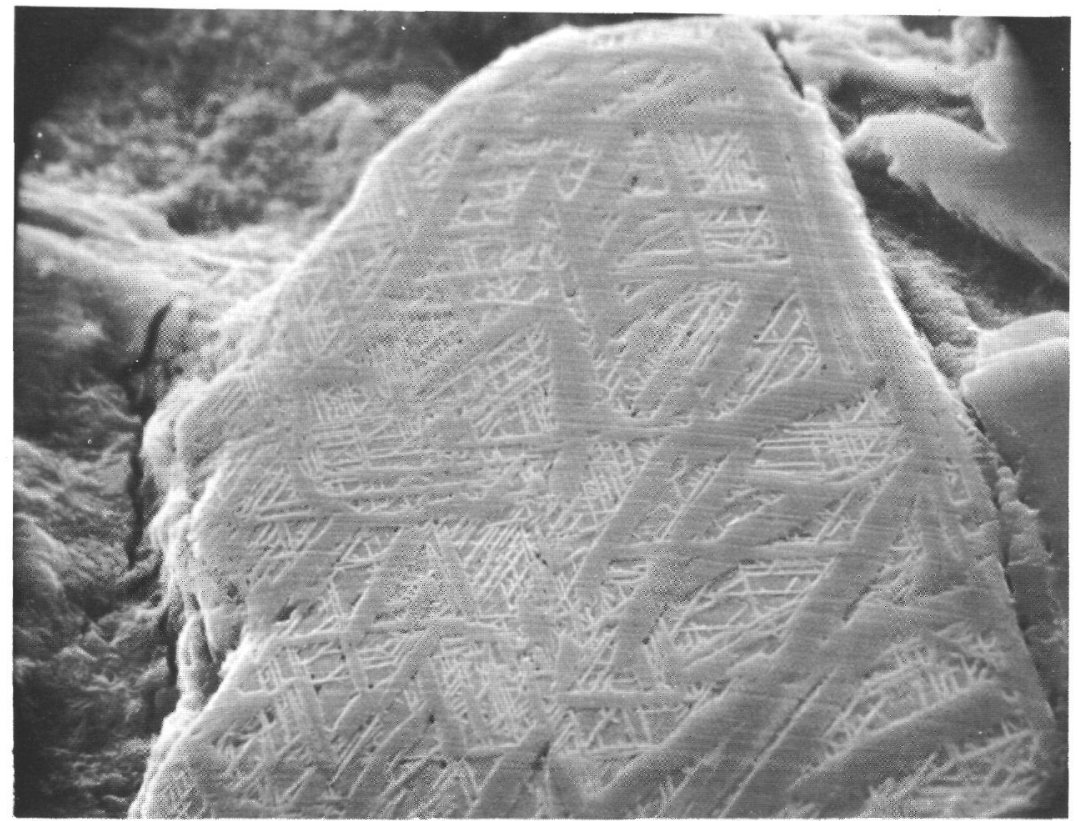

3a

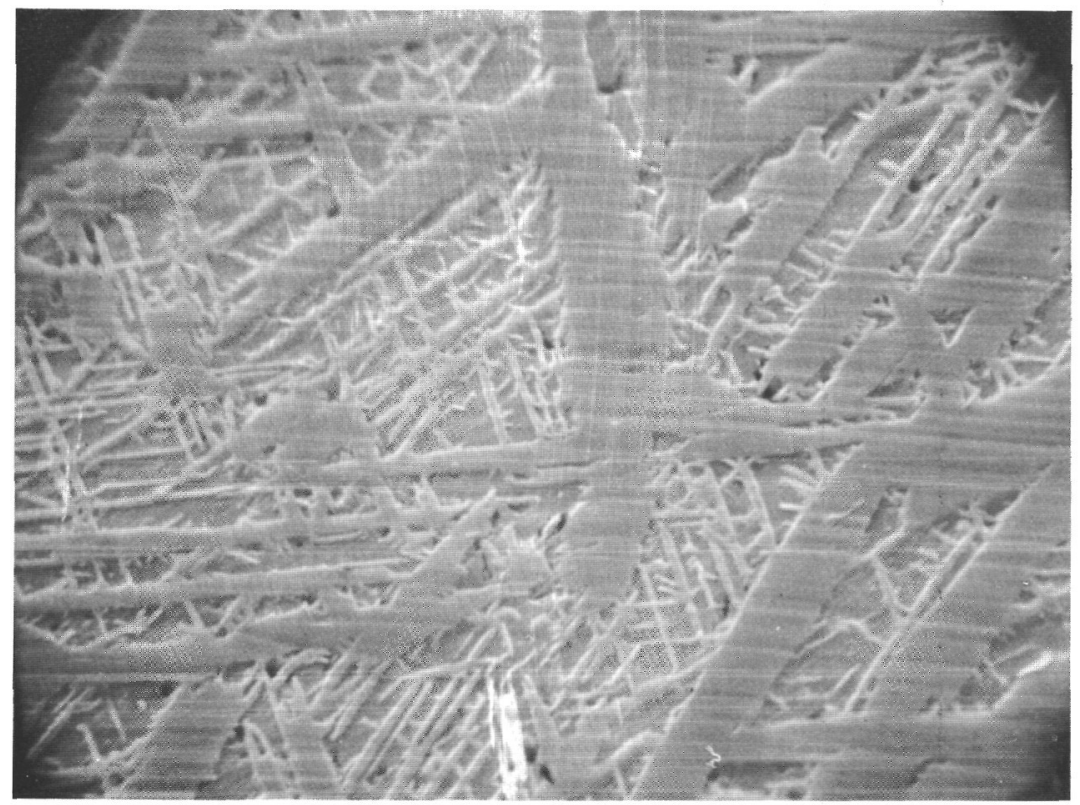

$3 b$

Figure 3. SEM photographs of Sample 432A-2-2, 72-74 cm, which is a typical example of moderate stage of high-temperature oxidation. (a) A titanomagnetite grain at a magnification of $2360 \times$. (b) The same grain at $5800 \times$. Note the development of very fine ilmenite lamellae (rod shaped).

as a datum in this figure, but the distributions are not much different when sample-average $x$ and $y$ (Table 7) are used. This figure shows that most of the hemoilmenite grains have a composition in a narrow range, $0.9<y$ $<1.0$, whereas the titanomagnetite grains show a wide variety in their composition centered around $x \approx 0.7$. In ocean floor basalts, $x$ of almost all the titanomagnetite (titanomaghemite) grains fall between 0.5 and 0.7 , with a mean value of about 0.65 (Johnson and Hall, 1978; Hamano et al., 1979). A wide range of $x$ values may be a characteristic property of subaerial basalts. Petersen (1976) summarized 237 analyses of titanomagnetites in basalts excluding ocean floor basalts, and obtained a mean of $x=0.61$. The $x$ values in his analysis range between 0.1 and 0.9 , while all the hemoilmenites have composition in the range $0.8<y<10$. The wide varia- 


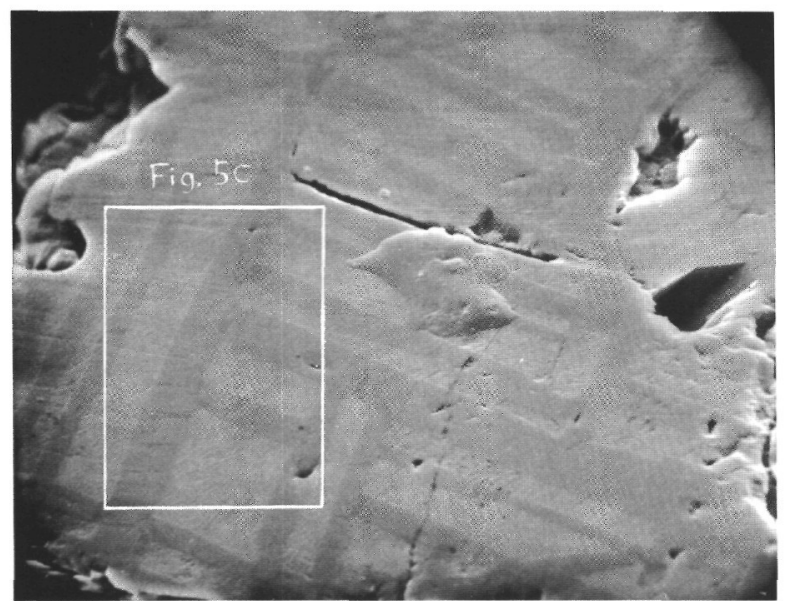

$4 a$

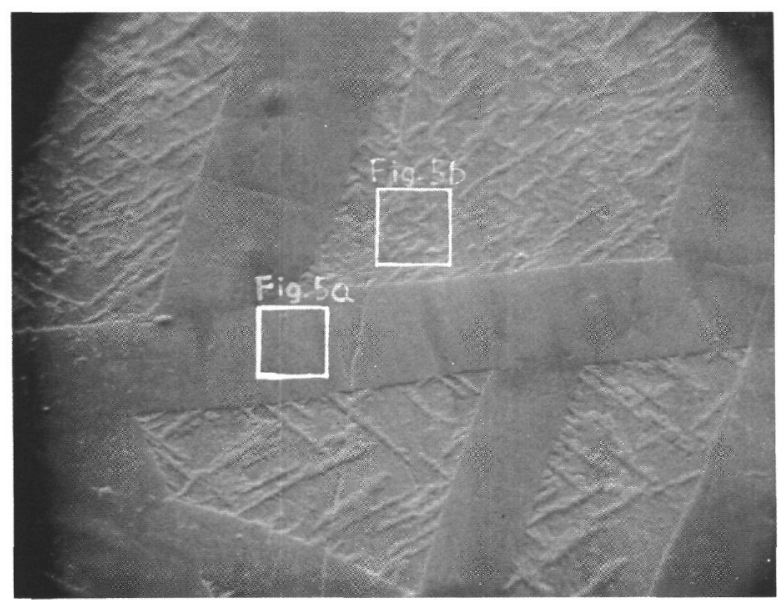

$4 \mathrm{~b}$

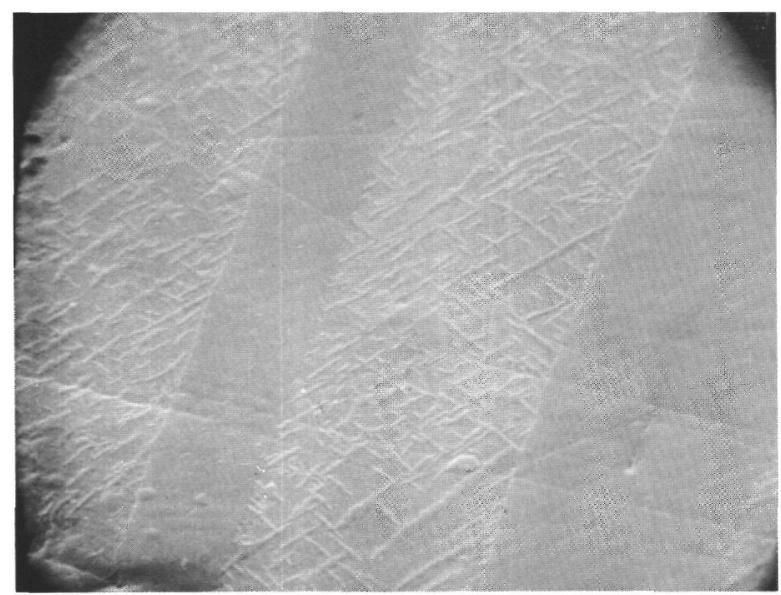

$4 \mathrm{c}$

Figure 4. SEM photographs of Sample 430A-5-5, 44-46 $\mathrm{cm}$, showing high stage of high-temperature oxidation. The areas of analyses of X-ray energy-dispersive spectra in Figure 5 are indicated by rectangles. (a) Titanomagnetite grain with ilmenite lamellae (darker bars) at a magnification of $1200 \times$. (b), (c) Different parts of the same grain at $6100 \times$. Note that the very tiny lamellae in the matrix are not parallel to the thicker ones, suggesting that they are of different crystal structure.
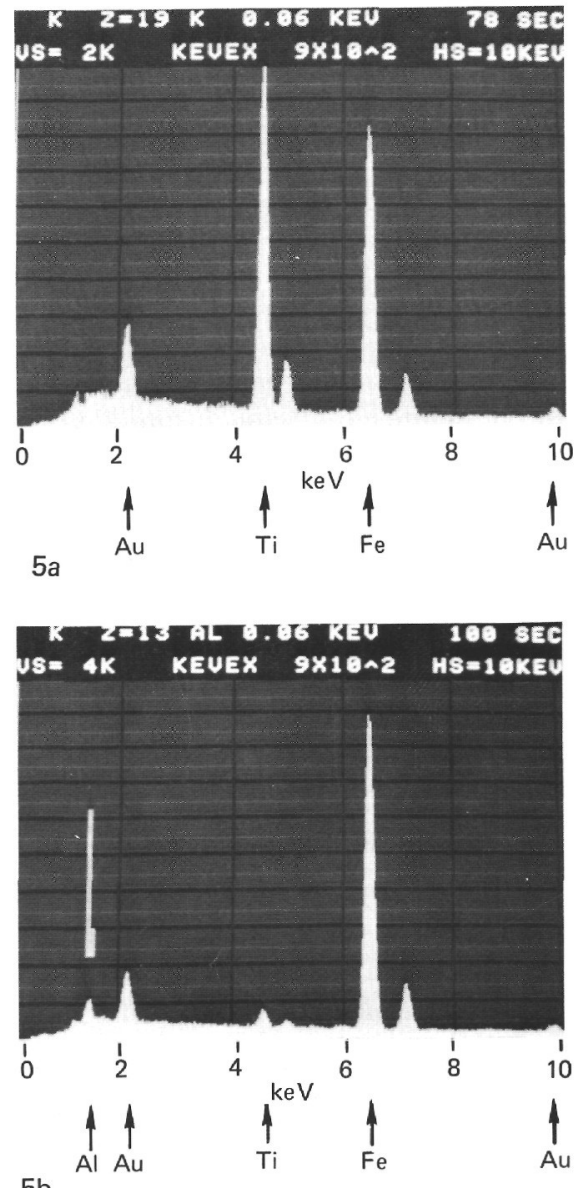

$5 b$

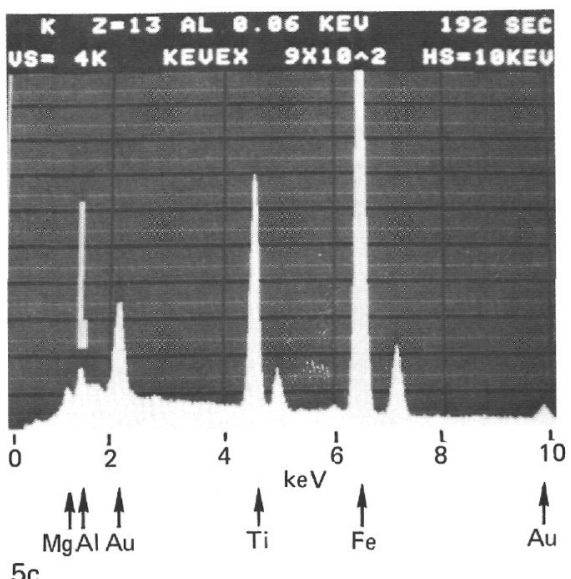

Figure 5. Energy-dispersive spectra of portions of titanomagnetites in Sample 430A-5-5, 44-46 cm. Relevant energy peaks are $\mathrm{Fe}, 6.4 \mathrm{keV}\left(K_{\alpha}\right), 7.1 \mathrm{keV}\left(K_{\beta}\right) ; \mathrm{Ti}$, $4.5 \mathrm{keV}\left(K_{\alpha}\right), 4.9 \mathrm{keV}\left(K_{\beta}\right) ; A l, 1.5 \mathrm{keV} ; M g, 1.3 \mathrm{keV}$. The peaks near $2 \mathrm{keV}$ and $10 \mathrm{keV}$ are due to $A$ u-coating of samples. (a) Inside an ilmenite lamella in Figure $4 b$, where $\mathrm{Ti}$ and $\mathrm{Fe}$ peaks dominate. (b) In matrix part in Figure $4 b$, where tiny lamellae exsolve. Note that Ti peak is very low and that Al is clearly present, while $\mathrm{Mg}$ peak is barely out of the background. The bars above the Al peak indicate expected $K_{\alpha}$ and $K_{\beta}$ emission lines of $A l$. (c) Overall composition. This time the $\mathrm{Mg}$ peak is more clearly evident. 
TABLE 4

Microprobe Analysis of Fe-Ti Oxides, Site 430 Basalts

\begin{tabular}{|c|c|c|c|c|c|c|c|c|c|}
\hline No. & $\mathrm{TiO}_{2}$ & $\mathrm{Al}_{2} \mathrm{O}_{3}$ & $\mathrm{Cr}_{2} \mathrm{O}_{3}$ & $\mathrm{FeO}$ & $\mathrm{MgO}$ & $\mathrm{MnO}$ & Total & $\begin{array}{c}\text { Titano- } \\
\text { magnetite: } x\end{array}$ & $\begin{array}{l}\text { Hemo- } \\
\text { ilmenite:y }\end{array}$ \\
\hline \multicolumn{10}{|c|}{$430 \mathrm{~A}-4-2,110-118 \mathrm{~cm}$} \\
\hline 1 & 19.61 & 0.95 & 0.00 & 69.99 & 2.26 & 0.38 & 93.19 & 0.604 & \\
\hline 2 & 19.63 & 0.64 & 0.00 & 69.76 & 2.38 & 0.43 & 92.84 & 0.606 & \\
\hline 3 & 21.41 & 0.63 & 0.00 & 68.45 & 2.71 & 0.44 & 93.64 & 0.659 & \\
\hline 4 & 30.70 & 0.40 & 0.00 & 59.84 & 1.88 & 0.24 & 93.06 & 0.947 & \\
\hline 5 & 31.67 & 0.47 & 0.00 & 61.16 & 1.91 & 0.29 & 95.50 & 0.953 & \\
\hline 6 & 40.31 & 0.45 & 0.00 & 49.90 & 3.08 & 0.68 & 94.42 & & 0.753 \\
\hline 7 & 41.98 & 0.31 & 0.00 & 49.58 & 3.90 & 0.65 & 96.42 & & 0.756 \\
\hline 8 & 49.09 & 0.21 & 0.00 & 46.14 & 2.73 & 0.68 & 98.85 & & 0.911 \\
\hline 9 & 52.01 & 0.21 & 0.00 & 37.07 & 3.34 & 0.41 & 93.04 & & 1.043 \\
\hline \multicolumn{10}{|c|}{$430 \mathrm{~A}-5-1,21-27 \mathrm{~cm}$} \\
\hline 10 & 14.87 & 1.62 & 0.00 & 76.75 & 0.93 & 0.39 & 94.56 & 0.445 & \\
\hline 11 & 37.82 & 0.24 & 0.00 & 53.93 & 1.36 & 0.23 & 93.58 & & 0.735 \\
\hline 12 & 43.50 & 0.16 & 0.00 & 50.41 & 1.88 & 0.35 & 96.30 & & 0.825 \\
\hline 13 & 44.64 & 0.34 & 0.00 & 48.28 & 2.50 & 0.45 & 96.21 & & 0.844 \\
\hline 14 & 44.44 & 0.26 & 0.00 & 48.13 & 2.46 & 0.44 & 95.73 & & 0.844 \\
\hline 15 & 49.18 & 0.30 & 0.00 & 44.62 & 3.13 & 0.49 & 97.72 & & 0.922 \\
\hline 16 & 49.71 & 0.26 & 0.00 & 41.88 & 3.04 & 0.50 & 95.39 & & 0.962 \\
\hline 17 & 50.25 & 0.16 & 0.00 & 44.55 & 2.89 & 0.48 & 98.33 & & 0.941 \\
\hline 18 & 50.85 & 0.18 & 0.00 & 40.73 & 3.55 & 0.56 & 95.87 & & 0.976 \\
\hline 19 & 51.71 & 0.17 & 0.00 & 42.32 & 3.18 & 0.60 & 97.98 & & 0.975 \\
\hline 20 & 55.27 & 0.23 & 0.00 & 38.23 & 2.37 & 0.44 & 96.54 & & 1.082 \\
\hline \multicolumn{10}{|c|}{$430 \mathrm{~A}-5-2,102-115 \mathrm{~cm}$} \\
\hline 21 & 17.38 & 1.45 & 0.00 & 73.74 & 1.72 & 0.44 & 94.73 & 0.525 & \\
\hline 22 & 16.38 & 1.05 & 0.00 & 75.23 & 1.04 & 0.46 & 94.16 & 0.491 & \\
\hline 23 & 16.73 & 0.93 & 0.00 & 74.92 & 0.95 & 0.37 & 93.90 & 0.502 & \\
\hline 24 & 18.41 & 1.09 & 0.03 & 72.75 & 1.25 & 0.42 & 93.95 & 0.556 & \\
\hline 25 & 17.28 & 1.31 & 0.03 & 73.41 & 1.36 & 0.43 & 93.82 & 9.524 & \\
\hline 26 & 46.97 & 0.18 & 0.00 & 45.13 & 2.44 & 0.46 & 95.18 & & 0.907 \\
\hline 27 & 47.33 & 0.14 & 0.00 & 45.77 & 2.30 & 0.50 & 96.04 & & 0.907 \\
\hline 28 & 46.45 & 0.17 & 0.00 & 46.36 & 2.01 & 0.49 & 95.48 & & 0.897 \\
\hline 29 & 47.27 & 0.16 & 0.00 & 46.41 & 2.15 & 0.48 & 96.47 & & 0.903 \\
\hline \multicolumn{10}{|c|}{$430 \mathrm{~A}-6-1,17-25 \mathrm{~cm}$} \\
\hline 30 & 16.60 & 0.82 & 0.03 & 72.79 & 1.47 & 0.59 & 92.30 & 0.511 & \\
\hline 31 & 22.71 & 0.64 & 0.01 & 70.64 & 0.74 & 0.42 & 95.16 & 0.673 & \\
\hline 32 & 15.60 & 0.96 & 0.00 & 73.11 & 1.25 & 0.61 & 91.53 & 0.483 & \\
\hline 33 & 19.84 & 0.81 & 0.00 & 71.12 & 0.95 & 0.34 & 93.06 & 0.602 & \\
\hline 34 & 21.58 & 0.84 & 0.00 & 69.57 & 1.16 & 0.46 & 93.61 & 0.654 & \\
\hline 35 & 49.29 & 0.19 & 0.00 & 47.20 & 1.84 & 0.50 & 99.02 & & 0.924 \\
\hline 36 & 48.91 & 0.19 & 0.00 & 45.73 & 3.08 & 0.52 & 98.43 & & 0.907 \\
\hline 37 & 50.05 & 0.18 & 0.00 & 45.06 & 2.84 & 0.57 & 98.70 & & 0.933 \\
\hline 38 & 49.31 & 0.14 & 0.00 & 46.28 & 2.93 & 0.57 & 99.23 & & 0.909 \\
\hline \multicolumn{10}{|c|}{$430 \mathrm{~A}-6-3,52-63 \mathrm{~cm}$} \\
\hline 39 & 22.10 & 1.50 & 0.00 & 68.86 & 2.39 & 0.65 & 95.50 & 0.672 & \\
\hline 40 & 23.48 & 0.77 & 0.00 & 66.82 & 2.20 & 0.59 & 93.86 & 0.720 & \\
\hline 41 & 18.93 & 1.02 & 0.05 & 72.50 & 1.35 & 0.45 & 94.30 & 0.570 & \\
\hline 42 & 21.14 & 1.36 & 0.04 & 70.36 & 2.20 & 0.55 & 95.65 & 0.638 & \\
\hline 43 & 22.95 & 1.14 & 0.02 & 68.59 & 1.91 & 0.64 & 95.25 & 0.694 & \\
\hline 44 & 51.25 & 0.14 & 0.27 & 42.45 & 1.68 & 0.29 & 96.08 & & 1.004 \\
\hline 45 & 51.27 & 0.16 & 0.50 & 43.48 & 2.24 & 0.50 & 98.15 & & 0.978 \\
\hline 46 & 54.43 & 0.11 & 0.00 & 40.75 & 2.12 & 0.39 & 97.80 & & 1.047 \\
\hline 47 & 50.58 & 0.19 & 0.50 & 44.63 & 2.11 & 0.63 & 98.64 & & 0.959 \\
\hline 48 & 46.67 & 0.12 & 0.43 & 46.95 & 1.14 & 0.58 & 95.89 & & 0.912 \\
\hline \multicolumn{10}{|c|}{$430 \mathrm{~A}-6-4,7-15 \mathrm{~cm}$} \\
\hline 49 & 22.07 & 0.76 & 0.00 & 69.20 & 1.39 & 0.44 & 93.86 & 0.669 & \\
\hline 50 & 17.05 & 0.98 & 0.00 & 73.65 & 1.08 & 0.41 & 93.17 & 0.517 & \\
\hline 51 & 17.83 & 0.61 & 0.00 & 73.15 & 0.84 & 0.29 & 92.72 & 0.539 & \\
\hline 52 & 20.63 & 1.05 & 0.00 & 69.58 & 1.42 & 0.33 & 93.01 & 0.631 & \\
\hline 53 & 19.98 & 1.33 & 0.00 & 70.51 & 1.52 & 0.50 & 93.84 & 0.609 & \\
\hline 54 & 47.60 & 0.40 & 0.00 & 43.95 & 2.69 & 0.71 & 95.35 & & 0.918 \\
\hline 55 & 52.68 & 0.23 & 0.00 & 41.25 & 1.67 & 0.32 & 96.15 & & 1.033 \\
\hline \multicolumn{10}{|c|}{$430 \mathrm{~A}-6-4,140-150 \mathrm{~cm}$} \\
\hline 56 & 25.20 & 1.23 & 0.00 & 66.28 & 1.40 & 0.82 & 94.93 & 0.764 & \\
\hline 57 & 22.65 & 0.79 & 0.00 & 68.82 & 0.88 & 0.63 & 93.77 & 0.685 & \\
\hline 58 & 23.37 & 1.01 & 0.00 & 68.43 & 0.76 & 0.45 & 94.02 & 0.705 & \\
\hline 59 & 19.74 & 1.35 & 0.03 & 72.98 & 0.80 & 0.50 & 95.40 & 0.587 & \\
\hline 60 & 49.56 & 0.17 & 0.00 & 48.25 & 1.42 & 0.34 & 99.73 & & 0.927 \\
\hline 61 & 49.30 & 0.20 & 0.12 & 48.09 & 1.46 & 0.32 & 99.49 & & 0.925 \\
\hline
\end{tabular}


TABLE 5

Microprobe Analysis of Fe-Ti Oxides, Site 432 Basalts

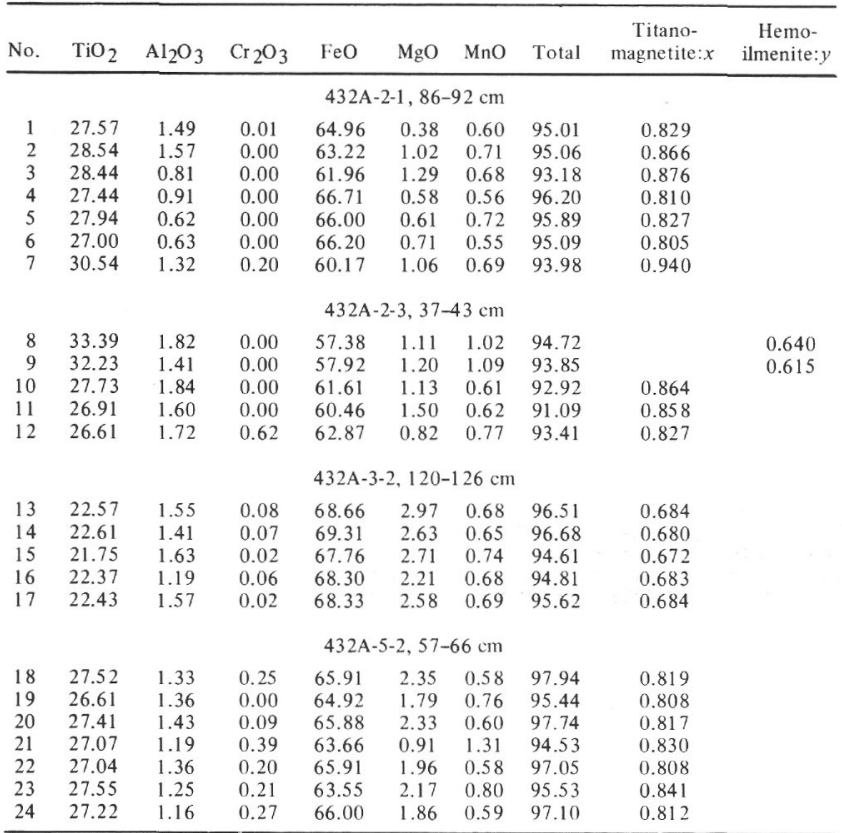

tion of $x$ may be a result of diffusion of metallic ions (Fe, $\mathrm{Ti}$ ) at high temperatures when high temperature oxidation is proceeding.

Sample-average compositions of titanomagnetites and hemoilmenites in Leg 55 basalts are shown in Table 7. Where four or more determinations of both $x$ and $y$ are available, the temperature and oxygen fugacity $\left(\mathrm{fO}_{2}\right)$ of equilibration were estimated by the method of Buddington and Lindsley (1964) and also given in this table. The temperatures and oxygen fugacities thus obtained range between 790 and $1200^{\circ} \mathrm{C}$ and $10^{-8.2}$ and $10^{-16.4}$ atm, respectively, but mostly lie between $960^{\circ} \mathrm{C}$ and $1100^{\circ} \mathrm{C}$ and between $10^{-10}$ and $10^{-12} \mathrm{~atm}$. These data distribute close to the fayalite-magnetite-quartz (FMQ) buffer in the temperature versus oxygen fugacity diagram, in agreement with the data of Carmichael and $\mathrm{Ni}$ cholls (1967). As discussed earlier, the composition of a mineral grain determined by microanalyzer is an average of an area a few micrometers across. In the present samples, however, chemical homogeneity cannot usually be expected for such an area in a grain, because the high-temperature oxidation caused the unmixing of titanomagnetite into Ti-rich and Ti-poor phases even at the sub-micrometer level. Therefore, these estimates should correspond to conditions at which separate titanomagnetite and hemoilmenite minerals were crystallized. Some of the samples show much lower temperature than the others (430A-6-3, 52-63 cm and 433C-42$1,56-63 \mathrm{~cm})$. They may correspond to the times when larger $(\sim 5 \mu \mathrm{m})$ ilmenite lamellae unmixed from the titanomagnetite host by high-temperature oxidation. It is quite certain that the Buddington-Lindsley method gives only the last equilibrium condition at some size level. High-temperature oxidation still proceeds at lower temperatures, but we cannot measure compositions of separate phases at this stage, because they are too small.
TABLE 6

Microprobe Analysis of Fe-Ti Oxides, Site 433 Basalts

\begin{tabular}{|c|c|c|c|c|c|c|c|c|c|}
\hline No. & $\mathrm{TiO}_{2}$ & $\mathrm{Al}_{2} \mathrm{O}_{3}$ & $\mathrm{Cr}_{2} \mathrm{O}_{3}$ & $\mathrm{FeO}$ & $\mathrm{MgO}$ & $\mathrm{MnO}$ & Total & $\begin{array}{c}\text { Titano- } \\
\text { magnetite: } x\end{array}$ & $\begin{array}{l}\text { Hemo- } \\
\text { ilmenite: } y\end{array}$ \\
\hline \multicolumn{10}{|c|}{$433 \mathrm{~A}-20-1,30-36 \mathrm{~cm}$} \\
\hline 1 & 23.39 & 0.91 & 0.00 & 66.47 & 1.45 & 0.68 & 92.90 & 0.721 & \\
\hline 2 & 22.32 & 1.02 & 0.00 & 68.61 & 1.29 & 0.64 & 93.88 & 0.679 & \\
\hline 3 & 21.66 & 1.04 & 0.00 & 69.67 & 1.20 & 0.69 & 94.26 & 0.655 & \\
\hline 4 & 21.07 & 1.15 & 0.00 & 70.84 & $\begin{array}{l}1.20 \\
1.27\end{array}$ & 0.62 & 94.95 & 0.633 & \\
\hline 5 & 19.86 & 0.54 & 0.00 & 72.59 & 0.50 & 0.52 & 94.01 & 0.592 & \\
\hline \multicolumn{10}{|c|}{$433 \mathrm{~A}-21-4,129-138 \mathrm{~cm}$} \\
\hline 6 & 25.67 & 1.06 & 0.14 & 67.31 & 1.27 & 0.45 & 95.90 & 0.766 & \\
\hline 7 & 19.96 & 1.38 & 0.00 & 71.83 & 1.42 & 0.42 & 95.01 & 0.600 & \\
\hline 8 & 19.41 & 1.56 & 0.00 & 70.42 & 1.56 & 0.48 & 93.43 & 0.596 & \\
\hline 9 & 17.50 & 1.43 & 0.00 & 74.46 & 0.84 & 0.52 & 94.75 & 0.523 & \\
\hline 10 & 14.88 & 1.71 & 0.00 & 75.21 & 1.32 & 0.41 & 93.53 & 0.453 & \\
\hline 11 & 14.40 & 1.40 & 0.00 & 75.97 & 1.02 & 0.45 & 93.24 & 0.437 & \\
\hline 12 & 54.36 & 0.18 & 0.00 & 41.33 & 1.92 & 0.51 & 98.30 & & 1.042 \\
\hline 13 & 47.08 & 0.39 & 0.00 & 47.64 & 2.31 & 0.68 & 98.10 & & 0.881 \\
\hline & & & & $433 \mathrm{~B}-$ & $-2,61-$ & $68 \mathrm{~cm}$ & & & \\
\hline 14 & 21.54 & 1.10 & 0.00 & 71.63 & 1.03 & 0.50 & 95.80 & 0.639 & \\
\hline 15 & 25.81 & 0.94 & 0.00 & 67.81 & 1.31 & 0.63 & 96.50 & 0.765 & \\
\hline 16 & 25.61 & 1.01 & 0.00 & 67.54 & 1.68 & 0.62 & 96.46 & 0.763 & \\
\hline 17 & 21.21 & 1.46 & 0.00 & 69.87 & 1.25 & 0.52 & 94.31 & 0.643 & \\
\hline 18 & 20.08 & 1.00 & 0.00 & 73.70 & 0.74 & 0.53 & 96.05 & 0.590 & \\
\hline 19 & 50.43 & 0.13 & 0.00 & 46.97 & 1.64 & 0.59 & 99.76 & & 0.942 \\
\hline 20 & 49.18 & 0.19 & 0.00 & 47.43 & 1.30 & 0.64 & 98.74 & & 0.930 \\
\hline & & & & 433B- & $-3,85-$ & $90 \mathrm{~cm}$ & & & \\
\hline 21 & 21.55 & 1.01 & 0.00 & 69.15 & 1.40 & 0.59 & 93.70 & 0.657 & \\
\hline 22 & 21.11 & 1.60 & 0.00 & 66.53 & 1.66 & 0.41 & 91.31 & 0.666 & \\
\hline 23 & 22.92 & 1.27 & 0.00 & 65.95 & 1.68 & 0.56 & 92.38 & 0.714 & \\
\hline 24 & 23.43 & 1.25 & 0.00 & 66.01 & 1.75 & 0.56 & 93.00 & 0.726 & \\
\hline 25 & 20.24 & 0.85 & 0.85 & 70.57 & 0.47 & 0.56 & 92.69 & 0.615 & \\
\hline & & & & $433 \mathrm{C}-$ & $-1,30-$ & $38 \mathrm{~cm}$ & & & \\
\hline 26 & 24.53 & 1.03 & 0.00 & 70.56 & 1.23 & 0.61 & 97.96 & 0.714 & \\
\hline 27 & 23.06 & 1.32 & 0.00 & 69.60 & 1.54 & 0.57 & 96.09 & 0.689 & \\
\hline 28 & 23.62 & 1.12 & 0.02 & 70.08 & 1.63 & 0.68 & 97.15 & 0.698 & \\
\hline 29 & 22.77 & 1.24 & 0.00 & 70.72 & 1.10 & 0.54 & 96.37 & 0.674 & \\
\hline 30 & 23.80 & 1.05 & 0.02 & 70.54 & 1.54 & 0.62 & 97.57 & 0.698 & \\
\hline 31 & 48.75 & 0.16 & 0.00 & 47.12 & 1.70 & 0.60 & 98.33 & & 0.921 \\
\hline 32 & 48.24 & 0.18 & 0.00 & 46.49 & 1.80 & $\begin{array}{l}0.00 \\
0.59\end{array}$ & 97.30 & & 0.920 \\
\hline 33 & 48.49 & 0.17 & 0.00 & 46.80 & 1.75 & 0.59 & 97.80 & & 0.920 \\
\hline 34 & 20.22 & 3.21 & 7.17 & 63.77 & 2.57 & 0.67 & 97.61 & 0.666 & \\
\hline 35 & 22.29 & 2.54 & 3.68 & 65.97 & 2.49 & 0.62 & 97.59 & 0.699 & \\
\hline 36 & 19.51 & 3.75 & 7.82 & 64.01 & 3.05 & 0.63 & 98.77 & 0.645 & \\
\hline & & & & $433 \mathrm{C}-1$ & $0-4,11$ & $.17 \mathrm{~cm}$ & & & \\
\hline 37 & 24.95 & 0.75 & 0.00 & 62.65 & 2.06 & 0.25 & 90.66 & 0.791 & \\
\hline 38 & 19.03 & 0.57 & 0.00 & 70.70 & 1.65 & 0.25 & 92.20 & 0.585 & \\
\hline 39 & 17.59 & 0.51 & 0.00 & 72.17 & 1.78 & 0.26 & 92.31 & 0.539 & \\
\hline 40 & 9.71 & 1.30 & 0.04 & 79.76 & 2.09 & $\begin{array}{l}0.20 \\
0.54\end{array}$ & 93.44 & 0.296 & \\
\hline 41 & 24.11 & 1.67 & 1.96 & 60.88 & 5.14 & 0.58 & 94.34 & 0.788 & \\
\hline & & & & $433 \mathrm{C}-1$ & $2-3,57$ & $65 \mathrm{~cm}$ & & & \\
\hline 42 & 23.69 & 2.70 & 0.00 & 65.61 & 0.99 & 0.33 & 93.32 & 0.735 & \\
\hline 43 & 21.26 & 2.54 & 0.00 & 66.60 & 1.25 & 0.63 & 92.28 & 0.669 & \\
\hline 44 & 20.91 & 2.30 & 0.00 & 69.38 & 0.88 & 0.45 & 93.92 & 0.640 & \\
\hline 45 & 12.82 & 3.10 & 0.00 & 76.76 & 0.61 & 0.43 & 93.72 & 0.392 & \\
\hline 46 & 4.44 & 1.75 & 0.06 & 79.59 & 0.92 & 0.27 & 87.03 & 0.143 & \\
\hline & & & & $433 \mathrm{C}-1$ & $3-2,55$ & $66 \mathrm{~cm}$ & & & \\
\hline 47 & 25.80 & 0.93 & 0.00 & 68.77 & 0.75 & 0.68 & 96.93 & 0.757 & \\
\hline 48 & 26.25 & 1.46 & 0.00 & 67.66 & 1.36 & 0.57 & 97.30 & 0.776 & \\
\hline 49 & 26.86 & 1.44 & 0.00 & 66.16 & 1.43 & 0.77 & 96.66 & 0.802 & \\
\hline 50 & 25.02 & 1.66 & 0.00 & 68.76 & 1.34 & 0.61 & 97.39 & 0.740 & \\
\hline 51 & 26.71 & 1.38 & 0.00 & 66.89 & 1.44 & 0.71 & 97.13 & 0.793 & \\
\hline 52 & 49.76 & 0.19 & 0.00 & 47.87 & 1.41 & 0.45 & 99.68 & & 0.932 \\
\hline 53 & 50.66 & 0.16 & 0.00 & 46.27 & 1.92 & 0.42 & 99.43 & & 0.948 \\
\hline 54 & 50.45 & 0.22 & 0.00 & 47.46 & 1.64 & 0.50 & 100.27 & & 0.938 \\
\hline 55 & 50.20 & 0.23 & 0.00 & 46.75 & 1.96 & 0.50 & 99.64 & & 0.936 \\
\hline 56 & 50.30 & 0.19 & 0.00 & 47.04 & 1.76 & 0.48 & 99.77 & & 0.939 \\
\hline & & & & $433 \mathrm{C}-$ & $4-3,8-$ & $15 \mathrm{~cm}$ & & & \\
\hline 57 & 27.66 & 1.92 & 0.00 & 61.82 & 0.79 & 0.40 & 92.59 & 0.861 & \\
\hline 58 & 21.66 & 1.61 & 0.00 & 68.63 & 0.66 & 0.34 & 92.90 & 0.663 & \\
\hline 59 & 26.12 & 1.80 & 0.00 & 64.59 & 0.56 & 0.36 & 93.43 & 0.800 & \\
\hline 60 & 27.15 & 1.85 & 0.00 & 62.69 & 0.82 & 0.42 & 92.93 & 0.841 & \\
\hline 61 & 28.48 & 1.54 & 0.00 & 61.99 & $\begin{array}{l}0.02 \\
1.10\end{array}$ & 0.41 & 93.52 & 0.877 & \\
\hline 62 & 49.55 & 0.22 & 0.00 & 47.70 & 0.81 & 0.54 & 98.82 & & 0.943 \\
\hline 63 & 50.91 & 0.26 & 0.00 & 46.15 & 0.95 & 0.44 & 98.71 & & 0.972 \\
\hline 64 & 49.00 & 0.27 & 0.00 & 47.26 & 0.70 & 0.52 & 97.75 & & 0.944 \\
\hline 65 & 53.99 & 0.22 & 0.00 & 41.95 & 0.97 & 0.40 & 97.53 & & 1.051 \\
\hline 66 & 50.59 & $\begin{array}{l}0.22 \\
0.23\end{array}$ & 0.00 & 45.68 & 0.87 & 0.46 & 97.83 & & 0.975 \\
\hline & & & & $433 \mathrm{C}-1$ & $5-6,16$ & $31 \mathrm{~cm}$ & & & \\
\hline 67 & 26.14 & 2.03 & 0.00 & 65.33 & 1.46 & 0.46 & 95.42 & 0.794 & \\
\hline 68 & 24.46 & 1.21 & 0.00 & 67.22 & 1.69 & 0.51 & 95.09 & 0.740 & \\
\hline 69 & 21.20 & 2.26 & 0.00 & 70.36 & 1.46 & 0.39 & 95.67 & 0.640 & \\
\hline 70 & 23.81 & 1.36 & 0.00 & 66.89 & 1.00 & 0.46 & 93.52 & 0.727 & \\
\hline 71 & 25.95 & 1.97 & 0.00 & 63.27 & 1.14 & 0.36 & 92.69 & 0.808 & \\
\hline 72 & 24.67 & 1.23 & 0.00 & 65.65 & 0.98 & 0.41 & 92.94 & 0.758 & \\
\hline 73 & 49.54 & 0.30 & 0.00 & 44.38 & 1.93 & 0.48 & 96.63 & & 0.956 \\
\hline 74 & 52.41 & 0.21 & 0.00 & 42.61 & 1.00 & 0.48 & 96.71 & & 1.026 \\
\hline
\end{tabular}


TABLE 6 - Continued

\begin{tabular}{|c|c|c|c|c|c|}
\hline & & & & & \\
\hline No. & $\mathrm{TiO}_{2}$ & $\mathrm{Al}_{2} \mathrm{O}_{3}$ & $\mathrm{Cr}_{2} \mathrm{O}_{3}$ & $\mathrm{FeO}$ & $\mathrm{MgO}$ \\
\hline & & & & $433 \mathrm{C}-19$ & $3-5,57-$ \\
\hline 75 & 21.98 & 0.99 & 0.00 & 68.09 & 0.53 \\
\hline 76 & 22.62 & 1.36 & 0.00 & 68.75 & 0.57 \\
\hline 77 & 23.88 & 1.68 & 0.00 & 65.09 & 0.69 \\
\hline 78 & 48.39 & 0.17 & 0.00 & 47.03 & 0.94 \\
\hline 79 & 48.19 & 0.15 & 0.00 & $\begin{array}{l}46.36 \\
4487\end{array}$ & 1.02 \\
\hline 80 & 49.78 & 0.23 & 0.00 & $\begin{array}{l}44.87 \\
46.31\end{array}$ & 1.12 \\
\hline 81 & 48.59 & 0.21 & 0.00 & 46.31 & 0.93 \\
\hline 82 & 48.84 & 0.16 & 0.00 & 46.61 & 0.94 \\
\hline & & & & $433 C-2$ & $1-4,7$ \\
\hline 83 & 14.89 & 1.13 & 0.00 & 70.40 & 1.85 \\
\hline 84 & 19.48 & 0.96 & 0.00 & 66.67 & 2.09 \\
\hline 85 & 15.75 & 0.63 & 0.05 & 68.41 & 1.72 \\
\hline 86 & 17.41 & 1.90 & 0.54 & 71.82 & 2.27 \\
\hline 87 & 47.22 & 0.20 & 0.00 & 47.79 & 2.44 \\
\hline 88 & 47.27 & 0.81 & 0.22 & 44.02 & 4.18 \\
\hline & & & & & \\
\hline & & & & $433 \mathrm{C}-2$ & $2-5,45-$ \\
\hline 89 & 23.43 & 1.28 & 0.16 & 67.75 & 2.25 \\
\hline 90 & 21.09 & 0.86 & 0.00 & 71.20 & 1.11 \\
\hline 91 & 29.47 & 0.73 & 0.00 & 62.00 & 1.84 \\
\hline 92 & 25.27 & 0.71 & 0.00 & 68.48 & 1.70 \\
\hline 93 & 21.44 & 1.06 & 0.03 & 71.63 & 1.34 \\
\hline 94 & 20.11 & 0.94 & 0.00 & 72.68 & 1.44 \\
\hline 95 & 50.52 & 0.20 & 0.00 & 46.13 & 2.34 \\
\hline 96 & 50.07 & 0.20 & 0.15 & 45.61 & 2.85 \\
\hline 97 & 50.63 & 0.24 & 0.00 & 45.69 & 2.90 \\
\hline 98 & 50.60 & 0.43 & 0.11 & 46.61 & 2.43 \\
\hline 99 & 29.50 & 1.46 & 1.97 & 64.45 & 2.75 \\
\hline & & & & & \\
\hline & & & & $433 \mathrm{C}-24$ & $7,133-$ \\
\hline 100 & 19.99 & 1.82 & 0.00 & 66.74 & 1.41 \\
\hline 101 & 24.57 & 1.50 & 0.00 & 62.95 & 1.73 \\
\hline 102 & 51.19 & 0.19 & 0.00 & 42.61 & 3.19 \\
\hline $10 \underline{3}$ & 52.05 & 0.24 & 0.00 & 41.95 & 3.43 \\
\hline $10 \overline{4}$ & 49.46 & 0.29 & 0.00 & 44.00 & 3.20 \\
\hline 105 & 52.17 & 0.27 & 0.00 & 41.14 & 3.46 \\
\hline 106 & 50.72 & 0.26 & 0.00 & 43.87 & 2.71 \\
\hline 107 & 51.14 & 0.29 & 0.00 & 41.98 & 5.51 \\
\hline 108 & 50.78 & 0.28 & 0.00 & 45.16 & 3.03 \\
\hline 109 & 53.18 & 0.19 & 0.00 & 39.43 & 3.88 \\
\hline & & & & $433 \mathrm{C}-2$ & $8-2,73$ \\
\hline 110 & 17.39 & 1.92 & 0.00 & 74.25 & 0.93 \\
\hline 111 & 21.13 & 1.68 & 0.00 & 70.35 & 1.15 \\
\hline 112 & 23.72 & 1.72 & 0.00 & 69.11 & 1.27 \\
\hline 113 & 24.75 & 1.56 & 0.00 & 68.27 & 1.32 \\
\hline 114 & 25.33 & 1.70 & 0.00 & 68.09 & 1.26 \\
\hline 115 & 25.05 & 1.67 & 0.00 & 68.48 & 1.36 \\
\hline 116 & 28.74 & 1.49 & 0.03 & 61.60 & 1.33 \\
\hline 117 & 48.84 & 0.57 & 0.00 & 47.30 & 1.82 \\
\hline 118 & 47.77 & 0.25 & 0.00 & 48.54 & 1.14 \\
\hline 119 & 49.67 & 0.30 & 0.00 & 48.39 & 1.41 \\
\hline 120 & 49.59 & 0.22 & 0.00 & 46.98 & 1.43 \\
\hline 121 & 48.48 & 0.34 & 0.00 & 47.24 & 1.48 \\
\hline 122 & 48.52 & 0.26 & 0.00 & 47.45 & 1.79 \\
\hline & & & & & \\
\hline & & & & $433 C-29$ & $-1,112$ \\
\hline 123 & 51.70 & 0.23 & 0.00 & 43.30 & 0.60 \\
\hline 124 & 49.00 & 0.16 & 0.00 & 48.52 & 0.87 \\
\hline 125 & 48.51 & 0.24 & 0.00 & 48.43 & 0.73 \\
\hline 126 & 48.57 & 0.26 & 0.01 & 48.88 & 1.04 \\
\hline 127 & 49.50 & 0.22 & 0.00 & 48.08 & 0.84 \\
\hline 128 & 48.03 & 0.24 & 0.02 & 49.32 & 1.03 \\
\hline & & & & & \\
\hline & & & & $433 \mathrm{C}-2$ & -2, 94- \\
\hline 129 & 22.68 & 0.94 & 0.04 & 68.33 & 0.87 \\
\hline 130 & 19.53 & 1.65 & 0.00 & 69.04 & 0.85 \\
\hline 131 & 23.97 & 0.87 & 0.00 & 65.05 & 0.97 \\
\hline 132 & 25.51 & 1.00 & 0.00 & 66.28 & 0.90 \\
\hline 133 & 26.25 & 1.37 & 0.00 & 64.91 & 1.20 \\
\hline 134 & 48.05 & 0.21 & 0.00 & 47.08 & 1.78 \\
\hline 135 & 50.99 & 0.23 & 0.00 & 45.87 & 1.47 \\
\hline & & & & & \\
\hline & & & & $433 \mathrm{C}-3$ & $1-1,28$ \\
\hline & & & & & \\
\hline $\begin{array}{l}136 \\
137\end{array}$ & $\begin{array}{l}22.13 \\
21.61\end{array}$ & 1.27 & 0.07 & $\begin{array}{l}71.45 \\
71.74\end{array}$ & \\
\hline 137 & 21.61 & 1.35 & 0.02 & $\begin{array}{l}71.74 \\
73.35\end{array}$ & $\begin{array}{l}1.76 \\
1.51\end{array}$ \\
\hline 138 & $\begin{array}{l}18.08 \\
48.54\end{array}$ & 2.18 & 0.20 & $\begin{array}{l}73.35 \\
45.76\end{array}$ & \\
\hline $\begin{array}{l}139 \\
140\end{array}$ & $\begin{array}{l}48.54 \\
49.45\end{array}$ & $\begin{array}{l}0.25 \\
0.45\end{array}$ & 0.00 & $\begin{array}{l}45.76 \\
45.77\end{array}$ & $\begin{array}{l}2.34 \\
2.36\end{array}$ \\
\hline $\begin{array}{l}140 \\
141\end{array}$ & $\begin{array}{l}49.45 \\
49.18\end{array}$ & $\begin{array}{l}0.45 \\
0.21\end{array}$ & 0.00 & $\begin{array}{l}45.77 \\
46.43\end{array}$ & $\begin{array}{l}2.36 \\
2.39\end{array}$ \\
\hline $\begin{array}{l}141 \\
142\end{array}$ & $\begin{array}{l}49.18 \\
49.45\end{array}$ & $\begin{array}{l}0.21 \\
0.22\end{array}$ & 0.00 & $\begin{array}{l}46.43 \\
45.54\end{array}$ & $\begin{array}{l}2.39 \\
2.75\end{array}$ \\
\hline $\begin{array}{l}142 \\
143\end{array}$ & $\begin{array}{l}49.45 \\
49.31\end{array}$ & $\begin{array}{l}0.22 \\
0.21\end{array}$ & 0.00 & $\begin{array}{l}45.54 \\
46.96\end{array}$ & 2.81 \\
\hline $\begin{array}{l}143 \\
144\end{array}$ & $\begin{array}{l}49.31 \\
48.77\end{array}$ & $\begin{array}{l}0.21 \\
0.24\end{array}$ & 0.00 & $\begin{array}{l}46.96 \\
46.50\end{array}$ & 2.69 \\
\hline $\begin{array}{l}144 \\
145\end{array}$ & $\begin{array}{l}48.77 \\
49.84\end{array}$ & 0.24 & 0.00 & $\begin{array}{l}46.50 \\
46.62\end{array}$ & $\begin{array}{l}2.09 \\
2.85\end{array}$ \\
\hline 145 & 49.84 & 0.24 & 0.00 & 46.62 & 2.85 \\
\hline & & & & $433 \mathrm{C}-34$ & $-2,103$ \\
\hline & & & & $433 c-34$ & 2,103 \\
\hline 146 & 19.95 & 1.63 & 0.06 & 66.41 & 0.75 \\
\hline 147 & 48.40 & 0.18 & 0.00 & 42.33 & 1.57 \\
\hline 148 & 48.14 & 0.18 & 0.00 & 44.06 & 1.39 \\
\hline 149 & 51.03 & 0.11 & 0.00 & 40.86 & 1.52 \\
\hline
\end{tabular}


TABLE 6 - Continued

\begin{tabular}{|c|c|c|c|c|c|c|c|c|c|}
\hline No. & $\mathrm{TiO}_{2}$ & $\mathrm{Al}_{2} \mathrm{O}_{3}$ & $\mathrm{Cr}_{2} \mathrm{O}_{3}$ & $\mathrm{FeO}$ & $\mathrm{MgO}$ & $\mathrm{MnO}$ & Total & $\begin{array}{c}\text { Titano- } \\
\text { magnetite: } x\end{array}$ & $\begin{array}{c}\text { Hemo- } \\
\text { ilmenite:y }\end{array}$ \\
\hline \multicolumn{10}{|c|}{$433 \mathrm{C}-47-5,92-100 \mathrm{~cm}$} \\
\hline 227 & 10.41 & 3.13 & 0.00 & 72.91 & 3.17 & 0.54 & 90.16 & 0.341 & \\
\hline 228 & 10.93 & 3.10 & 0.00 & 73.80 & 3.40 & 0.56 & 91.79 & 0.353 & \\
\hline 229 & 18.21 & 0.66 & 0.00 & 66.70 & 5.30 & 0.37 & 91.24 & 0.591 & \\
\hline 230 & 17.85 & 0.78 & 0.00 & 66.88 & 5.40 & 0.40 & 91.31 & 0.581 & \\
\hline 231 & 17.80 & 1.83 & 0.00 & 67.41 & 5.07 & 0.53 & 92.64 & 0.576 & \\
\hline 232 & 16.98 & 1.39 & 0.00 & 68.65 & 5.05 & 0.50 & 92.57 & 0.546 & \\
\hline 233 & 18.25 & 2.36 & 0.00 & 67.20 & 3.52 & 0.55 & 91.88 & 0.589 & \\
\hline 234 & 17.54 & 2.46 & 0.00 & 67.60 & 3.36 & 0.61 & 91.57 & 0.568 & \\
\hline \multicolumn{10}{|c|}{$433 \mathrm{C}-49-2,17-24 \mathrm{~cm}$} \\
\hline 235 & 25.96 & 1.57 & 0.06 & 64.41 & 0.80 & 0.42 & 93.22 & 0.798 & \\
\hline 236 & 23.53 & 1.40 & 0.00 & 65.55 & 0.87 & 0.48 & 91.83 & 0.732 & \\
\hline 237 & 24.38 & 1.50 & 0.34 & 67.65 & 0.53 & 0.39 & 94.79 & 0.734 & \\
\hline 238 & 24.48 & 1.43 & 0.06 & 68.15 & 0.66 & 0.48 & 95.26 & 0.732 & \\
\hline 239 & 23.23 & 2.30 & 2.40 & 67.59 & 0.50 & 0.54 & 96.56 & 0.708 & \\
\hline 240 & 22.71 & 1.48 & 0.74 & 68.93 & 0.67 & 0.52 & 95.05 & 0.686 & \\
\hline 241 & 25.92 & 1.48 & 0.11 & 64.71 & 0.77 & 0.49 & 93.48 & 0.794 & \\
\hline 242 & 26.05 & 1.62 & 0.05 & 64.40 & 0.88 & 0.44 & 93.44 & 0.800 & \\
\hline 243 & 25.33 & 1.47 & 0.05 & 65.61 & 1.20 & 0.48 & 94.14 & 0.773 & \\
\hline 244 & 23.83 & 1.64 & 1.76 & 65.96 & 1.03 & 0.49 & 94.71 & 0.736 & \\
\hline 245 & 25.36 & 1.44 & 0.00 & 65.87 & 0.93 & 0.44 & 94.04 & 0.772 & \\
\hline 246 & 52.56 & 0.34 & 0.00 & 42.21 & 2.48 & 0.29 & 97.88 & & 1.004 \\
\hline 247 & 52.89 & 0.33 & 0.00 & 41.93 & 2.49 & 0.34 & 97.98 & & 1.010 \\
\hline 248 & 51.76 & 0.34 & 0.00 & 42.71 & 2.66 & 0.35 & 97.82 & & 0.985 \\
\hline 249 & 50.01 & 0.14 & 0.00 & 46.25 & 0.95 & 0.55 & 97.90 & & 0.960 \\
\hline 250 & 49.55 & 0.19 & 0.00 & 46.83 & 0.79 & 0.48 & 97.84 & & 0.953 \\
\hline 251 & 49.54 & 0.19 & 0.00 & 45.42 & 0.70 & 0.39 & 96.24 & & 0.972 \\
\hline 252 & 49.53 & 0.19 & 0.00 & 48.84 & 0.87 & 0.56 & 99.99 & & 0.930 \\
\hline 253 & 49.41 & 0.18 & 0.00 & 48.83 & 0.89 & 0.60 & 99.91 & & 0.928 \\
\hline 254 & 49.87 & 0.19 & 0.00 & 46.72 & 0.96 & 0.45 & 98.19 & & 0.955 \\
\hline 255 & 50.70 & 0.16 & 0.00 & 46.15 & 0.89 & 0.43 & 98.33 & & 0.971 \\
\hline
\end{tabular}

Because of this limitation in resolution, application of the Buddington-Lindsley method requires special caution when subsolidus reactions occurred at the micrometer level.

\section{CONCLUSIONS}

Fe-Ti oxides in Leg 55 basalts were analyzed by optical microscope, scanning electron microscope, and $\mathrm{X}$-ray microanalyzer. Substantial differences exist be- tween the states of ferromagnetic minerals in the present samples and in typical oceanic basalts. Leg 55 basalts are characterized by universal occurrence of high-temperature oxidation, a high magnetic stability in consequence of the small effective grain size, and a wide range of composition of the titanomagnetite phase. These are typical properties of subaerial basalts. From these observations, we conclude that Leg 55 basalts (and perhaps most of the Emperor Seamounts basalts) were subaerially erupted, and that subsidence into the sea of the volcanic islands at later dates did not appreciably change the original ferromagnetic minerals. We do not support the widespread opinion that titanomagnetites in basalts of any origin alter to titanomaghemite at ambient temperatures if the basalts are submerged under the sea for a sufficiently long period of time $\left(\sim 10^{7}\right.$ years, e.g., Ozima et al., 1974). Leg 55 basalts also contain some titanomaghemites. The degree of low-temperature oxidation in Leg 55 basalts is usually quite low. Lowtemperature oxidation is confined to samples where high-temperature oxidation was of low or low to moderate degree, but none of the $\mathrm{H}$ and $\mathrm{M}-\mathrm{H}$ samples contain titanomaghemite. Low-temperature oxidation is abundant in Hole 432A (Ningoku) and absent in Hole 430A (Ōjin). In Hole 433C (Suiko), the occurrence of lowtemperature oxidation is not related to either type of rock or depth below the sea floor.

Observations by SEM reveal lamellar structure at a fraction of a micrometer. When ilmenite (and other) lamellae are well developed, the host becomes almost pure magnetite. The existence of spinel lamellae at fine scale was found by $\mathrm{X}$-ray energy-dispersive spectrum. The subdivision of magnetite host by lamellae is undoubtedly related to the nearly single-domain-like stability of
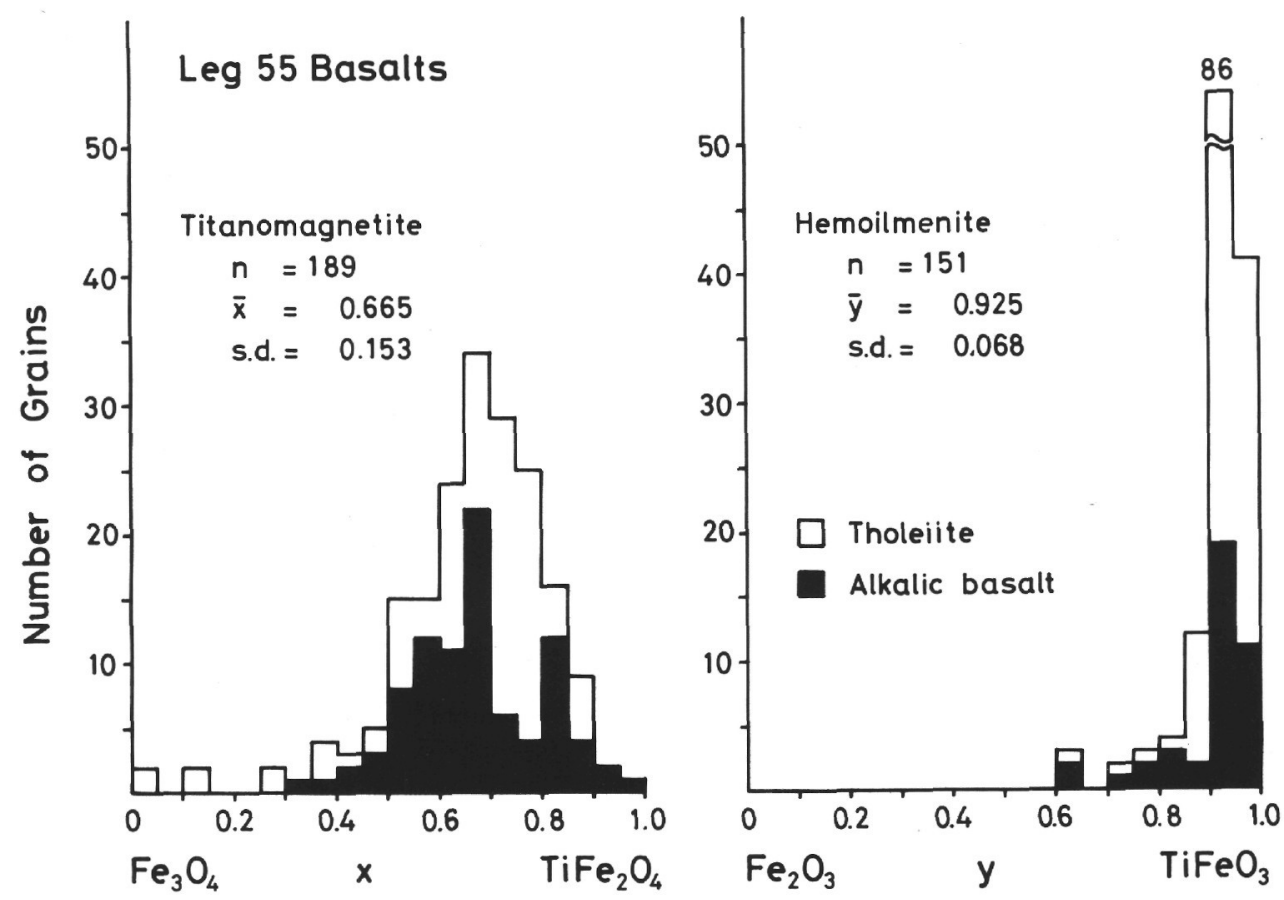

Figure 6. Distributions of composition parameters $\mathrm{x}$ of titanomagnetite and $\mathrm{y}$ of hemoilmenite in Leg 55 basalts, determined by microprobe analyses. 
TABLE 7

Average Compositions of Opaque Minerals

\begin{tabular}{|c|c|c|c|c|c|c|c|c|}
\hline \multirow{2}{*}{$\begin{array}{c}\text { Sample } \\
\text { (Interval in } \mathrm{cm} \text { ) }\end{array}$} & \multicolumn{3}{|c|}{ Titanomagnetite } & \multicolumn{3}{|c|}{ Hemoilmenite } & \multicolumn{2}{|c|}{$\begin{array}{c}\text { Buddington- } \\
\text { Lindsley } \\
\text { Temperature } \mathrm{fO}_{2} \\
(-\mathrm{log}\end{array}$} \\
\hline & n & $x$ & s.d. & $\mathrm{n}$ & $y$ & s.d. & $\left({ }^{\circ} \mathrm{C}\right)$ & $\left.f \mathrm{O}_{2}\right)$ \\
\hline $430 \mathrm{~A}-4-2,110-118$ & 5 & 0.754 & 0.181 & 4 & 0.866 & 0.140 & 1200 & 8.2 \\
\hline $5-1,21-27$ & 1 & 0.445 & & 10 & 0.910 & 0.099 & & \\
\hline $5-2,102-115$ & 5 & 0.520 & 0.025 & 4 & 0.903 & 0.005 & 960 & 11.4 \\
\hline $6-1,17-25$ & 5 & 0.584 & 0.085 & 4 & 0.918 & 0.012 & 970 & 11.4 \\
\hline $6-3,52-63$ & 5 & 0.659 & 0.058 & 5 & 0.980 & 0.050 & 790 & 16.4 \\
\hline $6-4,7-15$ & 5 & 0.593 & 0.064 & 2 & 0.976 & 0.081 & & \\
\hline $6-4,140-150$ & 4 & 0.685 & 0.074 & 2 & 0.926 & 0.001 & & \\
\hline $432 \mathrm{~A}-2-1,86-92$ & 7 & 0.851 & 0.048 & & & & & \\
\hline $2-3,37-43$ & 3 & 0.850 & 0.020 & 2 & 0.628 & 0.018 & & \\
\hline $3-2,120-126$ & 5 & 0.681 & 0.005 & & & & & \\
\hline $5-2,57-66$ & 7 & 0.819 & 0.012 & & & & & \\
\hline $433 A-20-1,30-36$ & 5 & 0.656 & 0.048 & & & & & \\
\hline $21-4,129-138$ & 6 & 0.563 & 0.121 & 2 & 0.962 & 0.114 & & \\
\hline 433B-5-2, 61-68 & 5 & 0.680 & 0.079 & 2 & 0.936 & 0.008 & & \\
\hline $5-3,85-90$ & 5 & 0.676 & 0.045 & & & & & \\
\hline $433 C-4-1,30-38$ & 8 & 0.685 & 0.022 & 3 & 0.920 & 0.001 & & \\
\hline $10-4,11-17$ & 5 & 0.600 & 0.205 & & & & & \\
\hline $12-3,57-65$ & 5 & 0.516 & 0.246 & & & & & \\
\hline $13-2,55-66$ & 5 & 0.773 & 0.026 & 5 & 0.939 & 0.006 & 1095 & 9.9 \\
\hline $14-3,8-15$ & 5 & 0.808 & 0.086 & 5 & 0.977 & 0.044 & 1030 & 11.5 \\
\hline $15-6,16-31$ & 6 & 0.744 & 0.060 & 2 & 0.991 & 0.049 & & \\
\hline $19-5,57-65$ & 3 & 0.701 & 0.037 & 5 & 0.949 & 0.014 & & \\
\hline $21-4,7-13$ & 4 & 0.539 & 0.062 & 2 & 0.883 & 0.001 & & \\
\hline $22-5,45-52$ & 7 & 0.728 & 0.120 & 4 & 0.933 & 0.004 & 1055 & 10.5 \\
\hline $24-7,133-139$ & 2 & 0.708 & 0.101 & 8 & 0.963 & 0.032 & 965 & 12.0 \\
\hline $28-2,73-80$ & 7 & 0.712 & 0.112 & 6 & 0.923 & 0.010 & 1060 & 10.3 \\
\hline $29-1,112-123$ & & & & 6 & 0.940 & 0.041 & & \\
\hline $29-2,94-100$ & 5 & 0.723 & 0.076 & 2 & 0.939 & 0.038 & & \\
\hline $31-1,28-34$ & 3 & 0.612 & 0.059 & 7 & 0.917 & 0.009 & & \\
\hline $34-2,103-111$ & 1 & 0.638 & & 3 & 0.985 & 0.034 & & \\
\hline $34-7,114-121$ & 4 & 0.431 & 0.160 & 3 & 0.825 & 0.101 & & \\
\hline $37-3,79-87$ & 6 & 0.721 & 0.025 & 4 & 0.923 & 0.002 & 1055 & 10.4 \\
\hline $38-1,67-76$ & & & & 13 & 0.891 & 0.076 & & \\
\hline $39-5,87-94$ & & & & 5 & 0.935 & 0.022 & & \\
\hline $40-2,88-96$ & 2 & 0.016 & 0.004 & 4 & 0.841 & 0.069 & & \\
\hline $42-1,56-63$ & 5 & 0.423 & 0.189 & 5 & 0.938 & 0.025 & 820 & 14.2 \\
\hline $42-3,11-20$ & 8 & 0.748 & 0.017 & 4 & 0.964 & 0.040 & 980 & 11.8 \\
\hline $42-5,85-92$ & 6 & 0.661 & 0.103 & 8 & 0.935 & 0.015 & 995 & 11.3 \\
\hline $47-5,92-100$ & 8 & 0.518 & 0.107 & & & & & \\
\hline $49-2,17-24$ & 11 & 0.751 & 0.038 & 10 & 0.967 & 0.028 & 980 & 12.0 \\
\hline
\end{tabular}

Notes: $\mathrm{fO}_{2}$ in atmospheres. All the samples from Hole $433 \mathrm{C}$, except $433 \mathrm{C}-4-1,30-38$ $\mathrm{cm}$ and $433 \mathrm{C}-47-5,92-100 \mathrm{~cm}$, are tholeiites. All the samples from the other holes are alka lic basalts (including hawaiites).

magnetization in these rocks. Because of such fine-scale structures in $\mathrm{Fe}-\mathrm{Ti}$ oxides, we point out the inherent ambiguity in application of the Buddington-Lindsley method to estimate the "last" equilibrium temperatures and oxygen fugacities.

\section{ACKNOWLEDGMENTS}

We are indebted to Penny Patterson (University of Colorado) for help in preparation of samples for and operation of the SEM. Yozo Hamano and Tadashi Nishitani (University of Tokyo) gave valuable comments. The Department of Microbiology of the University of Colorado kindly permitted us to use their SEM. The expenses of M.K. while in Boulder were defrayed by DSDP. We would like to express our gratitude to these persons and institutions.

\section{REFERENCES}

Ade-Hall, J. M., Khan, M. A., Dagley, P., and Wilson, R. L., 1968. A detailed opaque petrological and magnetic investigation of a single Tertiary lava flow from Skye, Scot-
land-I. Iron-titanium oxide petrology, Geophys. J. Roy. Astron. Soc., v. 16, pp. 375-388.

Ade-Hall, J. M., Palmer, H. C., and Hubbard, T. P., 1971. The magnetic and opaque petrological response of basalts to regional hydrothermal alteration, Geophys. J. Roy. Astron. Soc., v. 24, pp. 137-174.

Akimoto, S. and Kushiro, I., 1960. Natural occurrence of titanomaghemite and its relevance to the unstable magnetization of rocks, J. Geomag. Geoelect., v. 11, pp. 94-110.

Buddington, A. F. and Lindsley, D. H., 1964. Iron-titanium oxide minerals and synthetic equivalents, J. Petrol., v. 5, pp. 310-357.

Carmichael, I. S. E. and Nicholls, J., 1967. Iron-titanium oxides and oxygen fugacities in volcanic rocks, J. Geophys. Res., v. 72, pp. 4665-4687.

Creer, K. M. and Ibbetson, J. D., 1970. Electron microprobe analysis and magnetic properties of non-stoichiometric titanomagnetites in basaltic rocks, Geophys. J. Roy. Astron. Soc., v. 21, pp. 485-511.

Hamano, Y., Nishitani, T., and Kono, M., in press. Magnetic properties of basalt samples from Holes 417D and 418A. In Donnelly, T., Francheteau, J., Bryan, W., Robinson, P., Flower, M., Salisbury, M., et al., Initial Reports of the Deep Sea Drilling Project, v. 51, 52, 53, Part 2: Washington (U.S. Government Printing Office).

Johnson, H. P. and Atwater, T., 1977. Magnetic study of basalts from the Mid-Atlantic Ridge, lat. $37^{\circ} \mathrm{N}$, Geol. Soc. Am. Bull., v. 88, pp. 637-647.

Johnson, H. P. and Hall, J. M., 1978. A detailed rock magnetic and opaque mineralogy study of the basalts from the Nazca Plate, Geophys. J. Roy. Astron. Soc., v. 52, pp. 45-64.

Katsura, T., Kitayama, K., and Aoyagi, R., 1976. High temperature experiments concerning the Fe-Ti oxide minerals, Kazan (J. Volcanol. Soc. Japan), v. 21, pp. 31-56 (in Japanese with English abstract).

Larson, E. E., Ozima, M., Ozima, M., Nagata, T. and Strangway, D., 1969. Stability of remanent magnetization of igneous rocks, Geophys. J. Roy. Astron. Soc., v. 17, pp. 263-292.

Lowrie, W., 1977. Intensity and direction of magnetization in oceanic basalts, J. Geol. Soc., v. 133, pp. 61-82.

Marshall, M., 1978. The magnetic properties of some DSDP basalts from the north Pacific and inferences for Pacific plate tectonics, J. Geophys. Res., v. 83, pp. 289-308.

Ozima, M. and Larson, E. E., 1970. Low- and high-temperature oxidation of titanomagnetite in relation to irreversible changes in the magnetic properties of submarine basalts, $J$. Geophys. Res., v. 75, pp. 1003-1017.

Ozima, M., Joshima, M., and Kinoshita, H., 1974. Magnetic properties of submarine basalts and the implications on the structure of the oceanic crust, J. Geomag. Geoelectr., v. 26, pp. 335-354.

Petersen, N., 1976. Notes on the variation of magnetization within basalt lava flows and dykes, Pure Appl. Geophys., v. 114, pp. 177-193.

Readman, P. W. and O'Reilly, W., 1972. Magnetic properties of oxidized (cation-deficient) titanomagnetites ( $\mathrm{Fe}, \mathrm{Ti}$, $\square)_{3} \mathrm{O}_{4}$, J. Geomag. Geoelectr., v. 24, pp. 69-90.

Strangway, D. W., Larson, E. E., and Goldstein, M., 1968. A possible cause of high magnetic stability in volcanic rocks, J. Geophys. Res., v. 73, pp. 3789-3795.

Wilson, R. L. and Haggarty, S. E., 1966. Reversals of the earth's magnetic field, Endeavour, v. 25, pp. 104-109. 